IZA DP No. 9441

Tertiary Education and Prosperity:

Catholic Missionaries to Luminosity in India

Amparo Castelló-Climent

Latika Chaudhary

Abhiroop Mukhopadhyay

October 2015 


\title{
Tertiary Education and Prosperity: Catholic Missionaries to Luminosity in India
}

\author{
Amparo Castelló-Climent
}

University of Valencia

Latika Chaudhary

Naval Postgraduate School

\author{
Abhiroop Mukhopadhyay \\ Indian Statistical Institute \\ and IZA
}

\author{
Discussion Paper No. 9441 \\ October 2015
}

\author{
IZA \\ P.O. Box 7240 \\ 53072 Bonn \\ Germany \\ Phone: +49-228-3894-0 \\ Fax: +49-228-3894-180 \\ E-mail: iza@iza.org
}

Any opinions expressed here are those of the author(s) and not those of IZA. Research published in this series may include views on policy, but the institute itself takes no institutional policy positions. The IZA research network is committed to the IZA Guiding Principles of Research Integrity.

The Institute for the Study of Labor (IZA) in Bonn is a local and virtual international research center and a place of communication between science, politics and business. IZA is an independent nonprofit organization supported by Deutsche Post Foundation. The center is associated with the University of Bonn and offers a stimulating research environment through its international network, workshops and conferences, data service, project support, research visits and doctoral program. IZA engages in (i) original and internationally competitive research in all fields of labor economics, (ii) development of policy concepts, and (iii) dissemination of research results and concepts to the interested public.

IZA Discussion Papers often represent preliminary work and are circulated to encourage discussion. Citation of such a paper should account for its provisional character. A revised version may be available directly from the author. 


\section{ABSTRACT \\ Tertiary Education and Prosperity: Catholic Missionaries to Luminosity in India*}

This paper estimates the causal impact of tertiary education on luminosity across Indian districts. We address the potential endogeneity of tertiary education using the location of Catholic missionaries in 1911 as an instrument for current tertiary education. We find Catholic missionaries have a large and positive impact on tertiary education. Catholics were not at the forefront of tertiary education in colonial India, but they established many high quality colleges following Indian independence. Controlling for a rich set of geographical and historical characteristics, we find a positive causal effect of tertiary education on development, as measured by light density at night. The findings are robust to different measures of development, and are not driven by alternative channels through which missionaries could impact current income.

JEL Classification: $\quad$ I25, N35, O15

Keywords: $\quad$ human capital, Catholic missionaries, subregional analysis

Corresponding author:

Abhiroop Mukhopadhyay

B 10

Indian Statistical Institute

7 S.J.S. Sansanwal Marg

New Delhi 110016

India

E-mail: abhiroop@isid.ac.in

\footnotetext{
* We would like to thank participants at the $X^{\text {th }}$ Annual Conference on Economic Growth and Development, World Economic History Congress, Stanford Institute for Theoretical Economics Conference, ANAECO Workshop, and seminar participants at UNSW(Sydney), Monash University (Melbourne), Delhi School of Economics and CMI (Bergen) for their positive feedback. We are grateful to Federico Mantovanelli for sharing the historical maps and to Romain Wacziarg for his comments. This work would not have been possible without the effort put in by Athisii Kayina. We acknowledge the financial support from the Spanish Ministry of Economy and Competitiveness through ECO201129283 project, and the Planning and Policy Research Unit at the Indian Statistical Institute (Delhi). The views expressed in this article are those of the authors and do not reflect the official policy or position of the Department of Defense or the U.S. Government.
} 


\section{Introduction}

Identifying the fundamental determinants of development has a long pedigree in economics. A large literature relying largely on cross-country variation has emphasized the role of institutions (Acemoglu et al., 2001, 2002, 2014), geography (Sachs 2003), openness to trade (Frankel and Romer 1999), and human capital (Lucas 1998). Among these factors, the empirical evidence linking education to income has produced perhaps the weakest findings at the macro level (Benhabib and Spiegel 1994). The lack of a robust relationship between education and income is at odds with the vast labor literature, which finds strong causal effects of each additional year of schooling on individual earnings on the order of 10 to $15 \%$ across a wide set of countries (Card 2001). How do we reconcile the two sets of findings?

One explanation is perhaps that the macro literature has relied on incorrect measures of education. Most of the literature uses average years of schooling to capture education differences across countries (see Benhabib and Spiegel 1994; Cohen and Soto 2007; de la Fuente and Doménech 2007). The large number of people with no education skew average years of schooling for poor countries. Moreover, primary education is often of poor quality in these countries (Chaudhury et. al 2006), further exacerbating measurement problems. This may explain why years of education correlate poorly with economic outcomes at the macro level (Pritchett 2001). Another mutually nonexclusive explanation is the focus on cross-country analysis. The vast differences in culture, institutions and access to technology make it difficult to identify the causal effect of education on income. Problems of omitted variables and reverse causality plague many of the empirical studies (Acemoglu et al. 2014).

In this paper, we study the impact of tertiary education on development using data on Indian districts in 2006. The focus on a single country minimizes concerns of omitted variables because these sub-national units at least share common governance and national policies. Our focus on districts, an administrative unit below states, thus allows for tight comparisons because we exploit differences across districts within the same state using state fixed effects. This strategy allows us to address Acemoglu et al's (2014) concerns- that empirical studies treating institutions and human capital as exogenous are misspecified. Since institutions are mainly determined at the central and state level, the advantage of this approach is we can account for institutions without the need of an additional instrument. 
However, district-level data pose one problem in the Indian context - current income levels are not well measured. We address this shortcoming by using night lights data as a proxy for income, in line with the recent literature (see Henderson et al. 2012; Micholapoulos and Papaioannou 2013, 2014; Alesina et. al. 2012). We rely on information collected by the National Geophysical Data Center (NGDC) on the location of night lights between $8 \mathrm{pm}$ and 10pm, as captured by satellites of the United States Air Force Defense Meteorological Satellite Program (DMSP). Observations are available for an area of one squared kilometer and can be aggregated to the district level. To measure human capital, we focus on the share of the adult population with tertiary education, as only higher levels of education appear to be correlated with economic growth in India (e.g. Castelló-Climent and Mukhopadhyay 2013).

We find a strong positive association between the share of the population with tertiary education and light density at night in an OLS model that controls for state fixed effects. This relationship is robust to a rich array of factors that may jointly influence tertiary education and luminosity such as current population, population shares of socially disadvantaged groups, geographical characteristics, and historical variables that serve as initial states. The potential endogeneity of tertiary education, however, poses an empirical challenge because tertiary education and the evolution of income generally go hand in hand. We address this concern by using exogenous variation generated by the location of Catholic missionaries as of the early $20^{\text {th }}$ century to instrument for current tertiary education. Using the first edition of the Atlas Hierarchicus, we extract the exact geographical location of Catholic missionaries in 1911 and overlay the historical maps on district borders as of 2001 using a geographic information system (GIS) program.

The location of Catholic missionaries has to satisfy two conditions to be a valid instrument. First, the location of Catholic missionaries has to be unrelated to any factor that may impact the subsequent development of districts other than through current tertiary education. If Catholic missionaries historically located in richer and more educated districts, then the instrument would be invalid. Our reading of the history allays some of these fears. Catholic missionaries arrived in large numbers in India with European traders beginning in the $16^{\text {th }}$ century. The first wave of Catholic missionaries accompanied Portuguese traders and they located in Portuguese settlements along the coast such as Goa, Daman and Diu. Over time the missionaries moved inland and set up missions in South India and beyond depending on their location preferences. Historical accounts suggest the 
individual preferences of missionaries were important. They also considered places where the potential for proselytization was high and the hospitality of the local people or their rulers was more likely. In some cases this led to missionary strategies that focussed on bringing Hindu upper caste Brahmins into the fold; in other instances, it led to a focus on areas that had a large tribal population. Settling in economically developed areas seemed to have been of a lesser concern.

This account is supported by an empirical analysis of the historical data. Using a sample of districts from British India, we find no positive correlation between the location of Catholic missionaries and education variables in 1901. We also find no significant correlation between Catholic missionaries and measures of wealth such as income tax revenues. Thus, it does not appear Catholic missionaries located in richer districts with a higher potential to grow and develop. Consistent with the narrative above, we find that missionaries were more likely to locate in districts along the coast, in districts connected to a railway line and in districts with a larger share of tribal groups.

In our main empirical specifications, we also include many geographical and historical controls to address any potential selection concerns regarding the location of Catholic missionaries. First, geographic variables such as latitude, longitude, average height, average river length, and a coastal district indicator ensure we control for any positive selection in the choice of location vis-à-vis geography. Second, as Catholic missionaries may have chosen to locate in areas with more Brahmins (the traditional upper caste among Hindus) or more urbanized districts, we also include the historical composition of Brahmins and the urban population share of the district. Third, we include an indicator if a railway passed through the district in 1909 and the share of historically disadvantaged tribal groups, as they could have a direct influence on subsequent development. Finally, we include an indicator for districts that were historically part of Princely India and under the rule of hereditary kings as opposed to under direct British rule (British India) because Iyer (2010) shows that districts under Princely rule have better economic outcomes after independence. The inclusion of a rich set of controls, building on a detailed reading and analysis of history, ensure that the impact of historical Catholic missionaries is not confounded with location characteristics that may independently impact current development other than through current tertiary education.

To complete the story, however, it is important to discuss the link between Catholic missionaries and education. Indeed, in the colonial period, Catholics were less involved in 
the provision of education compared to the state, or even Protestants, who came later in the $19^{\text {th }}$ century. For example, there were only 9 Catholic colleges $(5 \%)$ compared to 40 Protestant colleges (33\%) as of 1911. The remaining colleges were either public or under private Indian management. Catholics were also largely absent from primary education. Early Catholic efforts were focused on training Indian priests and nuns, and on converting Indians to Christianity. The latter attempts met with limited success given the small number of Indian Christians (less than $2 \%$ of the total population by 1911). This point is further buttressed in the empirical analysis of historical data that finds no positive correlation between the location of Catholic missionaries and the number of schools or colleges in 1901. However, while Catholic missionary location does not correlate with education during colonial times, we find a large, positive and statistically significant effect of Catholic missionaries circa 1911 on the share of the 2001 adult population with tertiary education. One of the mechanisms driving this correlation is the establishment of many colleges after Indian independence. The historical network of Catholic missionaries was a natural platform from where Catholic influence on education radiated out. This is borne out in regressions that show the missionary location in 1911 correlate strongly with the stock of catholic colleges at the beginning of the $21^{s t}$ century. Anecdotal evidence suggests that this is a fall out of stronger funding from the Vatican, better co-ordination among the different Catholic groups and Indian independence in 1947, that guaranteed protection to minority institutions through an act in the new constitution. ${ }^{12}$

The strong correlation between the district tertiary education share in 2001 and the presence of catholic missionaries in 1911 highlights that our instrument meets the second condition for being a valid instrument. The tertiary education share is 1.2 percentage points higher in districts with a Catholic mission. This is a substantial effect on the order of $20 \%$ given mean tertiary education (5.8\%). Using Catholic missionaries as an instrument, the second stage results find a positive and statistically significant effect of tertiary education on current income as proxied by light density at night. A one standard deviation increase in the tertiary population increases log light density by 0.38 , an effect

\footnotetext{
${ }^{1}$ Article 30(1) of the Constitution of India gives linguistic and religious minorities a fundamental right to establish and administer educational institutions of their choice.

${ }^{2}$ The end of British colinization also marked a water shed for the growth of Catholic educational institutions as the British government followed an active strategy of dissuading missionary influence from provision of education in India. Moreover, an early emphasis on Indianizing the clergy also generated a large pool of Indian priests and nuns giving the Catholic church a unique advantage in post-independence India (Frykenberg 2008).
} 
of $9 \%$ given mean light density of 4.24 .

Although we find significant and positive IV estimates on tertiary education, one may still be concerned about whether Catholic missionaries impact current income via noneducation channels. Studies have found the historical presence of missionaries influence current religious beliefs and values (Nunn 2010). Acemoglu et al. (2014) highlight the interrelationship between human capital and institutions arguing that measures of human capital can capture the effect of institutions if some measure of institutions is not directly included in the analysis. In the case of India, Calvi and Mantovanelli (2014) find that proximity to a historical Protestant medical mission is correlated with current health outcomes. To ensure our results are not driven by these alternative mechanisms, we estimate specifications that control for measures of health, infrastructure, the current religious composition of the district, the share of migrants, and local historical institutions. The coefficient on tertiary education remains positive, statistically significant and stable across these specifications.

We conduct several tests that indicate the model does not suffer from a weak instruments problem and is not under-identified. Robustness checks also confirm that the coefficient on the share of tertiary education is not picking up the effect of other levels of schooling such as low primary education. And finally, we use alternative proxies for development such as GDP per-capita, measured by a private company, and find similar results.

Our paper contributes to three different literatures. First, a small and growing literature has begun to study the roots of development from a sub-national perspective. For example, Acemoglu and Dell (2010) examine sub-national variation in a sample of countries in the Americas and show that differences across regions within the same country are even larger than differences in income across countries. They find that about half the between-country and between-municipality differences in labor income can be accounted for by differences in human capital. In a similar vien, Gennaioli et al. (2013) find that human capital is one of the most important determinants of regional GDP per-capita in a large sample of regions covering 110 countries. Although the paper partially addresses endogeneity concerns using panel data techniques, their results cannot be interpreted as causal. The major contribution of our paper is the identification of a causal effect of tertiary education on development, using historical data as an exogenous source of variation in current human capital. 
Second, our paper contributes to a burgeoning literature on how history, in particular colonization, influences current outcomes. Acemoglu et al. (2001, 2002) argue that colonies with a more favorable disease environment encouraged more settlement of European colonizers and promoted institutions protecting private property rights. Engerman and Sokoloff (2000) also focus on historical institutional development, but argue that factor endowments shaped institutions. Areas predisposed to sugarcane production saw larger imports of slaves, establishment of slave plantations and more unequal institutions, whereas areas with higher land-labor ratios and small farms lead to egalitarian economic and political institutions. In contrast, Glaeser et al (2004) suggest that European settlers brought with them their own human capital and not institutions per se. Easterly and Levine (2012) compute a new measure of the share of European population during the early stages of colonization and the findings are in line with the Glaeser et al (2004) view. ${ }^{3}$ In this paper, by focusing on the intervention of Catholic missionaries in former colonies, we isolate a specific historical channel of human capital transmission. Unlike Banerjee and Iyer (2005) and Iyer (2010), that study how differences in formal colonial institutions impact current outcomes in India, our focus is on Catholic missionaries and how their historical location impacts human capital today. In our case, history influences the present through the historic location of Catholic missionaries that were absent from the provision of education in the past but played a bigger role after Indian independence. Our paper, therefore, proposes a novel instrument for the current levels of education.

Third and finally, our study contributes to the growing literature on religion and human capital. Much of this literature focuses on the positive impact of Protestants on education. For example, Becker and Woessmann (2009) find that Protestants had a strong effect on literacy in $19^{\text {th }}$ century Prussia. Mantovanelli (2014) argues that Protestant missionaries can account for current differences in literacy across India. Nunn (2014) compares Protestant to Catholic missionary activity in Africa and finds that both had a long-term positive impact on education. But, the impact of Protestant missionaries is stronger for women while the impact of Catholic missionaries is stronger for men. ${ }^{4}$ Studying Africa again,

\footnotetext{
${ }^{3}$ Other scholars stress the genetic distance relative to the world technological frontier (Spolaore and Wacziarg 2009) and the genetic diversity within populations (Ashraf and Galor 2013). See Spolaore and Wacziarg (2013) for an excellent survey of the literature.

${ }^{4}$ Becker and Woessmann (2008) examine village-level data from the Prussian Census of 1816 and identify a negative relationship between the prevalence of the Protestant religion and the educational gender gap, measured as average male education minus average female education.
} 
Gallego and Woodberry (2010) find that Protestant missionaries had a larger impact on long-term education than Catholics, but mainly in states where Catholic missionaries were protected from competition by Protestant missionaries. Our paper offers a new perspective to this literature. First, we find that only historic Catholic missionaries are correlated with current tertiary education in India and not Protestant missionaries. The impact of Catholic missionaries on the supply of tertiary education increased over the second half of the $20^{\text {th }}$ century as Catholics established colleges across India. Catholic emphasis on tertiary education is perhaps unsurprising and matches accounts of Catholics, especially the Jesuits, leading the growth of tertiary education in other parts of the world (Codina 2000). Second, most studies that analyze the long-term consequences of Christianity have focused on Africa and South America. Unlike these countries, the Christian population is a minority in India, with only a 2 percent share identifying as Catholic. Whereas Christianity has had a critical role in shaping some part of education, especially the influence of Catholics on elite education, their influence beyond education has been limited. Thus, looking at India is a good identification strategy for analyzing the impact of education on development.

The structure of the paper is as follows. The next section describes the data. In section 3 we present the OLS results and discuss potential biases. Section 4 discusses the instrumental variables strategy. Section 5 presents the main IV results. We describe several robustness checks in section 6 , and conclude in section 7 .

\section{Data}

Our analysis is conducted at the district-level, an administrative unit in India analogous to a US county. Empirical analyses that use historical data (or panel data) for India usually work with 13-16 major Indian states (of 1991 vintage). The common practice in all such papers is to drop small states (like Delhi) and the extreme north-eastern part of India. ${ }^{5}$ Analogous to previous work, our analysis is restricted to 500 districts in 20 states of India (of 2001 vintage) that cover more or less the same area as covered by other studies. ${ }^{6}$

\footnotetext{
${ }^{5}$ In the case of north-eastern India, this is largely to account for the poor quality of current data and problems of mapping historic boundaries to current boundaries.

${ }^{6}$ The number of states is dependent on the data available for the question being asked. For example, Besley and Burgess (2000) use 16 major states of India, whereas Banerjee and Iyer (2005) use district-level data from 13 major states. The states we study are Andhra Pradesh, Assam, Bihar, Chattisgarh, Gujarat, Harayana, Himachal Pradesh, Jammu and Kashmir, Jharkhand, Karnataka, Kerala, Madhya Pradesh,
} 
While district level data allow us to conduct sub-regional analyses, the main shortcoming in the Indian context is that statistical agencies do not report district-level GDP. To address this issue, we rely on night lights data. Recent work by Henderson et al. (2012) and Pinkovskiy (2013) suggest luminosity is a good proxy for income. ${ }^{7}$ The data on nightlight luminosity is recorded worldwide for every pixel by the Operational Linescan System (OLS) flown on the Defense Meteorological Satellite Program (DMSP) satellites. The data is available online from the US National Oceanic and Atmospheric Administration (NOAA). ${ }^{8}$ Following Michalopoulos and Papaioannou (2013), we use satellite images on light density at night as a proxy for economic development. We aggregate 2006 luminosity across all pixels within 2001 district boundaries. Then, we divide total luminosity by the area of the district to calculate light density at night. ${ }^{9}$ We calculate the log of this measure, as is standard in the literature. This measure varies from a minimum of -0.953 to a maximum of 6.407 with a mean of 4.24 . Figure 1 illustrates the night lights map and district-level luminosity side-by-side. In the district map, lighter colors correspond to higher luminosity. There is tremendous heterogeneity in luminosity across Indian regions such as between the South (high luminosity) and East (low luminosity). Nevertheless, there is also heterogeneity between contiguous districts. Our analysis explores whether tertiary education can account for differences in luminosity across districts within the same state.

In the regressions we focus on the population aged 25 years and above ensuring the completion of tertiary education is not censored by age. Using the 2001 census of India, we construct current district-level demographic and education variables. The main independent variable of interest is the share of population 25 years and above who have completed tertiary education. ${ }^{10}$ Although $5.8 \%$ of the population over 25 has completed any tertiary

Maharashtra, Orissa, Punjab, Rajasthan, Tamil Nadu, Uttar Pradesh, Uttaranchal and West Bengal. The larger number of states as compared to the cited studies reflect the bifurcation of states between 1991 and 2001.

${ }^{7}$ Chen and Nordhaus (2010) note some problems with satellite image data but argue that luminosity is still useful for regional analysis especially when income data are poor.

${ }^{8}$ Data are available on http://ngdc.noaa.gov/eog/dmsp/download_radcal.html

${ }^{9}$ We take calibrated radiance data for a year for which high resolution sensors were used. Hence, in our exercise, luminosity is measured from 0 to 255 for each pixel, with 0 measuring no light. This is in contrast to some papers that use luminosity data that are censored from above at 64 . We use GIS tools to extract luminosity from the raster files provided by DMSP.

${ }^{10}$ We include those with degrees or diplomas in general education and professional education. We do not include school level diplomas in our definition of tertiary education. 
education, the range extends from a low of $1.4 \%$ to a high of $21.3 \%$. Figure 2 shows the spatial distribution of tertiary education across Indian districts. Analogous to the figure on luminosity, a lighter color represents a higher share of adults with completed tertiary education. While it is clear that South India has higher tertiary completion rates, again there is significant heterogeneity within states.

Tertiary education flourished in British India despite a low and stagnant level of literacy (just over 10\% in 1931). Enrollment rates in arts and professional colleges increased six fold between 1891 and 1941 from $0.05 \%$ to $0.35 \%$ (Chaudhary 2015). In comparison, primary school enrollment in 1941 was only twice as much as in 1891 with one-third of school-age children attending any primary school in 1941. Most of the increase in tertiary education was driven by private demand because administrative positions in colonial government offices often required a college degree. Unlike the recent increase, this early development in tertiary education occurred in the liberal arts and not in technical degrees. After Indian independence in 1947, the policy focus switched to increasing and improving the number of people with technical degrees. Unfortunately, the census enumeration of education at the district-level has evolved over time making it difficult to follow the share of the population with completed tertiary education. The best we can do is follow a consistent definition of graduate degree holders and above, which indicate the share of graduate degree holders increased from $0.5 \%$ of the population in 1971 to $3.1 \%$ in 2001 .

The unconditional correlation between district log light density and share of 2001 tertiary education is 0.46 . Figure 3 shows the scatter plot between the two variables. While the pictures suggests a large and positive correlation between luminosity and tertiary education, the correlation could be driven by confounding variables correlated with the two. To address this concern, we control for a broad array of factors that include current controls, geographic characteristics, and historical variables.

The list of current controls include the district population aged 25 years and above as well as the share of historically disadvantaged population groups 25 years or older, referred to as Scheduled Castes and Scheduled Tribes under the Indian constitution. The data are taken from the 2001 Census. The list of current variables is necessarily parimonious, a point we discuss below.

To capture geographic characteristics, we construct an indicator variable for districts with any coastal boundary, the latitude and longitude of the centroid of the district, the average length of rivers that pass through the district, the average altitude of the district, 
and the minimum distance from the centroid of the district to one of the million plus population cities of India. ${ }^{11}$ The geographical variables are constructed using GIS tools. We include these variables to account for any direct impact of geography on development (Sachs 2003) and also to correct for any systematic bias that geography may cause in measuring night lights.

We rely on variables sourced from the historical 1931 census of India to capture differences across districts in initial states that may have impacted current tertiary education and income. We focus on several historical variables: the urban population share in 1931, the tribal population share in 1931, the population share of Brahmins in 1931, the districts that were historically a part of Princely India, and the presence of railways in 1909. ${ }^{12}$ Brahmins typically occupy the top position in the Indian caste system. Although they traditionally worked as priests and teachers, Brahmins were disproportionately represented among landowners, lawyers and other elite occupations in the colonial era. Thus, the Brahmin population share may independently influence both subsequent tertiary education and development. We also create an indicator variable for districts that were historically a part of Princely India, i.e., under the direct control of hereditary rulers in the colonial period as opposed to under direct British rule (i.e., British India). The native rulers faced different incentives that may impact the subsequent development of education and income. Finally, we use the railway map in the Administration Report on Indian Railways for 1909 to construct an indicator for the presence of railways, as more accessible places are likely to have more educated people and can influence development per se. We report summary statistics for the main variables in Table 1.

\section{Tertiary Education and Luminosity: OLS Estimates}

We begin by estimating an OLS model using the share of the population over 25 who have completed tertiary education as our key independent variable (tertiary) and the log of

\footnotetext{
${ }^{11}$ The million plus cities as of the 2001 census are Ahmedabad, Bangalore, Chennai, Delhi, Hyderabad, Jaipur, Mumbai, Pune and Surat. The files to extract the average height and the average river length is obtained from http://www.diva-gis.org/

${ }^{12}$ We combine the cross-walk of Bharadwaj et al. (2008) from 1931 to 1951 followed by Kumar and Somanathan (2008) for 1971 to 2001 to match 1931 district-data to 2001 districts. We impute the same proportion to all districts in 2001 that are contained in consistent district units between 1931 to 2001 . In few cases, these units cover a large number of districts because of district boundary changes over time.
} 
light density at night $(y)$ as our measure of development. The empirical model we estimate is :

$$
y_{d s}=\alpha+\sum \beta_{s} D_{s}+\theta \text { tertiary } y_{d s}+\rho^{\prime} C_{d s}+\pi^{\prime} G_{d s}+\delta^{\prime} H_{d s}+\varepsilon_{d s}
$$

where $d$ denotes a district and $s$ stands for state. We eliminate the impact of omitted variables that vary at the state level by including state fixed effect: $D_{d s}$. The within state comparison removes the effects of state-level policies (both current and past) that covary with tertiary as well as state-level omitted variables. The use of within state variation, in contrast to inter-state variation, also eliminates cultural differences towards education and development. For instance, the differences in human capital between North and South India are often ascribed to differences in culture. We account for some of the observed differences by including the vector $\mathrm{C}$ of current variables, described above. We also take into account a vast empirical literature that has documented a strong correlation between geographical characteristics and current levels of income per capita. ${ }^{13}$ We model $y$ as a function of time invariant characteristics with the vector of geographical controls, $G$.

The list of current controls is parsimonious by intention. We exclude most current variables because they are likely endogenous to factors influencing contemporary luminosity. Instead, we take into account different initial conditions across districts through a set of historical controls, $H$. These variables account for the evolution of other contemporaneous variables, for example, current urbanization, that are not included in our specification due to potential endogeneity. ${ }^{14}$ We estimate the model using robust standard errors. ${ }^{15}$

Table 2 reports the results for the base-line OLS specification. A comparison across columns shows the impact of controlling for other covariates on the coefficient for tertiary education. Unsurprisingly, the addition of contemporaneous and geographic controls reduces the magnitude of the coefficient on tertiary education. The marginal effect of increasing the share of tertiary education by one standard deviation (0.03) in the model with no controls (column (1)) increases the log light density by 0.43 (mean value is 4.24 ). The marginal effect drops to 0.30 once we include all controls (column (4)). This is an

\footnotetext{
${ }^{13}$ Whether geographical factors have a direct impact on contemporaneous development or indirectly throuch its persistent historical effects is still under debate. See Nunn (2014) and Spolaore and Wacziarg (2013) for excellecnt surveys on the literature.

${ }^{14}$ In Section 6 we analyze the robustness of the results to additional contemporaneous controls.

${ }^{15}$ We do not cluster standard errors at the state level because the number of states (17) are too few to generate accurate clustered standard errors (Angrist and Pischke 2009). As a robustness check we estimated p-values from wild bootstrap suggested by Cameron, Gellbach and Miller (2008) as a solution to the problem of few clusters. Our results on tertiary education are still significant.
} 
economically significant effect on the order of $7 \%$ against the mean of log light density. Results also indicate that geographical characteristics, the share of tribal groups, and the presence of a railway line in 1909 are significantly related to current income levels.

One concern with using only the share of tertiary education is that the omitted category is the population share that is illiterate, has not completed primary education or has completed only up to secondary schooling. The share of tertiary education may differ across districts because of differences in primary schooling or illiteracy, apart from any differences in tertiary education. Hence, the coefficient on tertiary education may be picking up the effect of other levels of schooling. To address this concern, we directly control for the share of population with some schooling but no higher than secondary education (column 5). For ease of exposition, we refer to this variable as share of secondary schooling in the tables and text. The coefficient on tertiary education remains positive and statistically significant at the 1 percent level. As expected, the coefficient is smaller, but it is nonetheless economically significant. This suggests the findings on tertiary education are not driven by omitting other levels of schooling.

The results so far point to a strong correlation between the share of population with tertiary education and log light density at night, which is robust to a broad array of controls, and is not driven by lower levels of schooling. However, this relationship cannot be interpreted as causal. The main challenge to ascribing a causal interpretation is that the share of tertiary educated is likely to be endogenous. Reverse causality is a serious concern if individuals with tertiary education move to districts with higher income or higher light density. Although migration is low between Indian states (Munshi and Rozensweig, 2009), people are more mobile within states. Moreover, less is known about the migration of tertiary educated labour within India. In order to obtain consistent estimates, we therefore need to address the issue of endogeneity. To this end, we turn to history and the role of Catholic missionaries.

\section{Catholic Missionaries to Luminosity}

In this section we first describe the history of Catholic missionaries and then discuss why the location of missionaries is a good instrument for 2001 tertiary education. 


\subsection{Catholic Missionaries}

According to popular accounts, the apostle St. Thomas travelled to South India in the $1^{\text {st }}$ century A.D. (CSMC 1923). While it is unclear if the visit impacted the local population, an ancient group of Indian Christians (the St. Thomas Christians) with roots predating the arrival of Europeans believe they spiritually descended from the apostle St. Thomas. Concentrated in Kerala, St. Thomas Christians represent the earliest mention of Catholics in India. ${ }^{16}$

Barring an occasional mention of Catholic priests, church history in India is silent till the arrival of Vasco de Gama and the Portuguese in Calicut in 1498. Along with their trading interests, the Portuguese had a strong desire to spread Catholicism in their overseas colonies (Richter 1908). To this end, Portuguese rulers enjoyed special ecclesiastical privileges, the Padroado Real. Granted by the Pope in 1452 and 1455, these charters gave the Portuguese Crown "exclusive authority to fill clerical positions within overseas domains" (Frykenberg 2008, p. 127). Rome believed that allowing the Portuguese Crown to appoint bishops and collect church taxes in exchange for establishing churches and missionaries was a low-risk high-return strategy. But, subsequent Popes came to regret granting such extensive privileges to foreign monarchs.

Under Padroado Real, the first Catholic missions were set up in India in the $16^{\text {th }}$ century. The Franciscans and Dominicans were dominant early on but were taken over by the Jesuits after the arrival of Francis Xavier, co-founder of the Society of Jesus, in 1542. Missionary efforts were concentrated on the western coast and Goa become the center of Portuguese Catholic Church hierarchy. Missionaries also settled early in Portuguese strongholds such as Daman, Diu, Vasai (suburban area north of Mumbai), and Mumbai along the coast. Corroborating these accounts $78 \%$ of the Catholic missionaries we observe in 1911 are located in coastal districts.

While the early missionaries followed Portuguese conquest, missionaries also settled in the interior away from Portuguese strongholds. Our reading suggests the individual preferences of missionaries played a role. For example, an enterprising Jesuit named Robert de Nobili moved to the cultural city of Madurai, pretended to be an upper caste Hindu

\footnotetext{
${ }^{16}$ St. Thomas Christians, also known as Syrian Christians, had many historical disputes with the Catholic Church for example, the language of liturgy, Syrian or Latin, and promoting native clergy. Rome addressed these concerns in the late $19^{\text {th }}$ century. Since then the two churches of St. Thomas Christians, the Syro-Malabar Church and Syro-Malankara Church, have become an important part of the Catholic Church in India. See Frykenberg (2008) for details.
} 
and established the Madurai Mission to recruit high caste Brahmins into the Catholic fold. There are accounts of Jesuit missionaries following Nobili's methods, as well as non-Jesuit missionaries working to convert lower castes and tribes (CSMC 1923). Akbar allowed Catholics to set up missions in Gujarat but the missionaries chose the location. Historical centers of trade and production were not always the natural choice. In Bengal, the first mission was set up in Hooghly and not the important port city of Calcutta.

As Portuguese rule declined over the $17^{\text {th }}$ century, Catholic missions fell into disarray. While they had enjoyed Portuguese political patronage, neither the native Indian rulers nor the English East India Company were sympathetic to the Catholic cause. The suppression of the Jesuits in the $18^{\text {th }}$ century compounded the problem because they were the most active Catholic missionaries in the field. Finally, ecclesiastical disputes between the Propaganda Fide, a society backed by Rome, and the Padroado Real backed by Portugal made it difficult for all Catholic missionaries. These differences were resolved by Pope Leo XIII in 1885 with a charter that established the Indian Catholic Church. Most jurisdictions were placed directly under Rome, or the Propaganda Fide barring two, the Archdiocese of Goa and the Diocese of Mylapore, near modern-day Chennai.

After the establishment of the Hierarchy, the Catholic Church embarked on a extensive program of education in $20^{\text {th }}$ century India. The main goals were to develop a dedicated native Indian clergy and high quality schools and colleges. Again the Jesuits lead the charge after their return in the $19^{\text {th }}$ century. India today has more Jesuit priests at 3,851 than any other country despite the fact that less than $2 \%$ of the population is Catholic (Frykenberg 2008). These trained priests have contributed to the rise of many high quality Jesuit schools and colleges that are among the best in the country. The historical network of Catholic missionaries was a natural platform from where Catholic influence on education spread. Corroborating the qualitative accounts, we find the large expansion in Catholic colleges occurred only after Indian Independence. In section 6, we document the growth in Catholic colleges over time, and show that the missionary location in 1911 has a strong positive correlation with the stock of catholic colleges in 2001.

\subsection{Identification}

Our empirical exercise uses the location of Catholic missionaries in the early $20^{\text {th }}$ century as an instrument for 2001 tertiary education. We obtained the location of Catholic missionaries from a map published in the first edition of Atlas Hierarchicus, which marks 
the name of every place in India where there was a Catholic mission or missionary in 1911 (Figure 4). This historical map is super-imposed on the 2001 district map of India to yield the location of Catholic missionaries in terms of 2001 district boundaries. Figure 5 displays Catholic locations after this exercise. As noted above, a majority of the missionaries are located along the coast in former Portuguese colonies. But, a sizable number are present inland with more in peninsula India than in the North or the East. We use the location of Catholic missionaries to construct an indicator variable taking the value 1 if, in 1911, there was a Catholic missionary in the area covered by district $d$ in 2001 . We believe a simple indicator is more exogenous compared to an intensive measure of the number of Catholic institutions or say number of Catholic institutions per square kilometer, which is likely to be correlated with the historical presence of Christians in a district. ${ }^{17}$

The presence of Catholic missionaries has to satisfy two conditions to be a valid instrument. First, the instrument has to be correlated with tertiary education in 2001. In the next section we provide compelling evidence that districts with a historical presence of Catholic missionaries are significantly correlated with tertiary education in 2001. Further, conventional weak instrument tests, such as the F-statistic and the Cragg-Donald Wald statistic, indicate the instrument is strong. Second, the location of Catholic missionaries as of 1911 has to be uncorrelated with the error term, i.e., unobservable factors that may influence current light density. The location of Catholic missionaries can violate the exclusion restriction in two ways. In the first place, Catholic missionaries may have located in richer or more educated areas. Secondly, the exclusion restriction can be violated if the location of Catholic missionaries impacts contemporary luminosity through channels other than contemporary tertiary education. In this section we analyze the endogenous location of Catholic missionaries. In Section 6 we examine other potential channels through which Catholic missionaries could affect current development.

Catholic missionaries could have located in richer or more educated districts that could independently impact current development. The main concern here is whether Catholics positively selected districts. To assess the potential exogeneity of Catholic missionaries, we collected information on a sub-sample of districts for the period before our map of Catholic locations was published in 1911. This smaller sample of districts covers the British Indian provinces of Bengal, Bihar and Orissa, Bombay and Madras where we have decent data

\footnotetext{
${ }^{17}$ Our IV results are robust to using such intensive measures and to controlling for the historical share of Christians. These results are available upon request.
} 
on education and measures of income. In Table $3 A$ we regress the presence of a Catholic missionary in a district in 1911 on geography and other historical variables from 1901 . We show the effects of geography on the entire sample of 500 districts (Column (1)), and then for the sub-sample of districts where we have historical information ((Columns (2)-(3)). The impact of geography is similar across the two samples, which suggests we can draw cautious conclusions about the full-sample based on this selected sample.

Catholic missionaries were more likely to be located in coastal districts, in districts with a railway presence and in districts with a larger share of tribals. While coastal districts and railways indicate positive selection, tribal districts are indicative of negative selection. Reassuringly, we find the location of Catholic missionaries is uncorrelated with the share of Brahmins and income tax revenues per capita, a proxy for income. We also find that the number of schools are not correlated with the presence of catholic missionaries. In fact, the selection is negative; the coeffiecient on the number of colleges is significant but negative. This is consistent with the historical record that Catholic missionaries were less involved in education relative to Protestant missionaries. For example, there were only 9 Catholic colleges (5\%) in 1911 compared to 40 Protestant (33\%). ${ }^{18}$ The rest were either public or under private Indian management. Public schools were more widespread at the primary and secondary level, but again Catholics were largely absent. These correlations are suggestive that the location of Catholic missionaries was not systematically correlated with historical measures of income or education. Moreover, the fact that missionaries located in coastal areas and in districts with a higher share of tribal groups is an indication that Catholic missionaries did not follow a single strategy.

Most studies on Christian missionaries focus on Protestants. In keeping with that literature, we also constructed an indicator variable for districts with a Protestant mission as of 1908 using information in the Statistical Atlas of Christian Missions (1908). We observe Protestant missionaries in $58 \%$ of the districts. Their location is closely tied to the strength of the East India Company and British Crown (Richter, 1908). Hence, we worry more about the potential exogeneity in their choice of location. Interestingly, Protestants were actively involved in education in the colonial era, but lost their dominance after Independence. Despite their alleged stance of religious neutrality, the British Crown was more favorable to Protestant missionaries compared to Catholics. Hence, the loss of informal state patronage probably hurt the Protestants in post-1947 India. Similar

\footnotetext{
${ }^{18}$ We constructed these averages based on information in the Progress of Education in India (1911-12).
} 
to Table $3 A$, we ran regressions on the location of Protestant missionaries and historical characteristics reported in Table $3 B$. In the case of Protestants, the coastal indicator has even larger predictive power. Protestants also set up missions in more ethnically diverse districts and those at a higher altitude. But, the correlation between Protestant missionaries and the provision of education is again insignificant.

In the main regressions we would like to control for all historical variables pre-dating Catholic missionary location. ${ }^{19}$ Apart from the geographical variables and railways, which measure accessibility, there is no data to control for historical characteristics before the $20^{\text {th }}$ century. Hence, we control for historical characteristics in the first year the data are available, namely 1931. The first colonial census was conducted in 1872, but these early censuses were unreliable. More systematic enumeration began with the 1891 census, but information on the Princely States that account for one-third of the colonial Indian population was reported for aggregate regions, not individual states. Some of the information on the Princely States was also incorrectly enumerated in the early censuses. ${ }^{20}$ We use the 1931 census because it has the most detailed and accurate information on the Princely States and districts of British India. Migration and urbanization was low and largely unchanged in the colonial era, so these historical variables are decent, though not ideal, proxies. The social characteristics proxy for missionaries positively selecting districts with more Brahmins, urbanized areas and better connected places by the presence of railways, or negatively selecting districts with more tribal groups. Whether the district was a part of Princely India is also important because Christian missionaries were more common in British India. ${ }^{21}$ If the location of Catholic missionaries are correlated with initial conditions that we control for in the main regressions, there is less of a concern because we are already accounting for that observable historical characteristic.

\footnotetext{
${ }^{19}$ Although we do not know the date when Catholic missionaries first arrived in a district, we believe it was either decades before or immediately after the establishment of the Catholic hierarchy in 1885 . Not many Catholic missions were established in the early to mid- $19^{\text {th }}$ century and Catholic missionaries were mostly dormant in this period. The older Portuguese missions were set up in the $16^{\text {th }}$ and $17^{\text {th }}$ centuries.

${ }^{20}$ For example, literacy is incorrectly enumerated in the 1901 census for the Central India Agency States.

${ }^{21}$ This effect is especially strong for Protestant missionaries but nonetheless also negative and significant for Catholic missionaries. Including an indicator for a historical Princely State is problematic because these areas were not randomly selected making the indicator potentially endogenous. Our OLS and IV results on tertiary education are the same whether we include a Princely State dummy, and we choose to show the results with this variable because they were more Catholic missionaries in British India.
} 


\section{Tertiary Education and Luminosity: IV Estimates}

\subsection{Main Results}

We present the IV results in Table 4. Moving across the columns we add more controls, with column (4) being the complete specification. The first stage results, displayed in Panel $A$, show the indicator for Catholic missionaries is positive and significant across specifications, with the magnitude going down as we add more controls. In column (4), which includes our full set of controls, the marginal effect of Catholic missionaries on contemporary tertiary education is 0.015 . Thus, the population share of individuals with tertiary education is $25 \%$ higher in districts with a Catholic missionary given the mean tertiary education share of 0.058 . This rather large point estimate is highly significant. Reassuring, we do not suffer from a weak instrument problem; the $F$ stat is 20 and the Cragg-Donald Wald statistic is $28 .^{22}$ Other interesting results from the first stage show that districts with centroids closer to big cities and those with a higher urbanization rate in 1931 have more tertiary education today. As expected, a large presence of disadvantaged communities is negatively correlated with tertiary education. ${ }^{23}$

Second stage results are displayed in Panel B. The IV coefficient on tertiary education is positive and significant at the 1 percent level with a magnitude of 12.97 (column (4)). A standard deviation increase in tertiary education raises log light density by 0.39 , an economic effect of $9 \%$ given mean light density. One standard deviation of tertiary education is equivalent to a 3 percentage point higher tertiary completion rate, as compared to the omitted share. The omitted share, by construction, is a combination of those who are illiterate, those with some schooling, those who have passed high school but not gone ahead to complete tertiary education.

As noted in our OLS results, one may argue the share of tertiary education is picking up the impact of other levels of schooling. In column (5) we address this issue by including the share of population with some schooling but no higher than secondary schooling. The IV coefficient on tertiary education is positive and significant, while the coefficient on schooling is not statistically significant. Moreover, the coefficient on tertiary education is

\footnotetext{
${ }^{22}$ The null hypothesis is that the instrument is sufficiently weak that the 2SLS estimator is at least $b$ percent as biased as the OLS estimator. The criticical values provided by Stock and Yogo (2005) for values of $b=10 \%, 15 \%, 20 \%$ and $25 \%$ bias are $16.38,8.96,6.66$ and 5.53 respectively. We reject the null hypothesis as the Cragg-Donald Wald statistic exceeds the corresponding critical values.

${ }^{23}$ In the interests of parsimony, we do not report these results, but they are available upon request.
} 
similar in magnitude to the estimate in column (4), which confirms the omission of lower levels of education is not driving our results on tertiary education.

\subsection{Endogeneity of Secondary Schooling}

Although we control for the share of secondary schooling in Table 4, this raises a problem because this share is not exogenous. Moreover, the positive correlation between secondary and tertiary education may render the coefficient on secondary education insignificant in column (5). Hence, we need an instrument for secondary schooling. The location of Protestants missionaries offers one possibility given the burgeoning literature showing a positive impact of Protestant missions or missionaries on literacy. The principle of "Sola Scriptura" underpins the relationship between the Protestant religion and literacy because the Bible is the supreme authority in matters of doctrine and practice and one has to be literate to read the Bible. According to Gallego and Woodberry (2009) and Nunn (2012) this lead Protestant missionaries to promote education around the world. Studies have linked Protestants to literacy in Germany (Becker and Woessmann 2008) and India (Mantovanelli 2014). Scholars have also used variation in Protestant missionaries as an instrument for education (Acemoglu et al. 2014).

Following this literature we use the location of Protestant missionaries as of 1908 as an instrument for lower levels of education in 2001. Table 5 presents the results using the two instruments: Catholic and Protestant missionaries to instrument for the share of the population with tertiary education and the population with secondary education. ${ }^{24}$ The first stage for tertiary education shows a large and positive coefficient on Catholic missionaries, and a positive but insignificant coefficient on Protestant missionaries. This corroborates our understanding of the post-1947 education landscape when many Catholic colleges came on the scene and accounts for the persistent impact of Catholic missionaries on contemporary tertiary education. Since Protestants focused more on basic literacy, it is perhaps unsurprising we find no impact of Protestant missionaries on tertiary education. This also indicates that our Catholic instrument is not just picking up the impact of Christian missionaries more generally.

Similar to the literature, we find Protestant missionaries had a positive impact on the

\footnotetext{
${ }^{24}$ If we use Protestant and Catholic missionaries as joint instruments for just tertiary education, we find similar results as in Table 4. The Hansen over-identification test in the parsimonious and full specification displays p-values equal to 0.144 and 0.973 respectively, giving further evidence of the exogeneity of the instruments.
} 
share of the adult population with some schooling but no higher than secondary schooling. Districts with Protestant missionaries in 1908 are positively correlated this secondary school completion share in 2001. However, we interpret these results with caution because of the low values of the Cragg-Donald and Kleibergen-Paap rk Wald tests. The location

of Protestant missionaries seems to be a weak instrument for schooling. ${ }^{25}$ In fact, the Kleiberger-Paap p-value in column (1) indicates the model is under-identified. As we have two endogenous variables, the model can be under-identified if only one of the instruments is valid. In our case only Catholic missionaries appear to be a valid instrument for tertiary education.

The second stage results are similar to the previous findings, again highlighting that our main IV results in Table 4 are not picking up the effect of other levels of education. The coefficient on tertiary education is less significant than earlier models because the combination of Protestant and Catholic missionaries are weak instruments jointly for tertiary and secondary education.

\section{Sensitivity Analysis}

\subsection{Is location of Catholic missionaries a plausible instrument?}

Our identification relies on the assumption that Catholic missionaries affect current luminosity through their influence on tertiary education. We report two pieces of evidence in support of this assumption. In Table 6, we first show that the presence of Catholic missionaries in a district in 1911 is uncorrelated with the provision of education and education outcomes in the colonial period. Catholic missionaries are positively correlated with the number of Catholic colleges only after Indian independence. In columns (1) and (2), we use the total literacy rate and English literacy rate in 1931 as dependent variables. In this context, English literacy is a better measure of tertiary education because most colleges used English as the language of instruction. The coefficient on Catholic missionaries is small and insignificant. In columns (3) to (6), we study the correlation between Catholic missionaries and the number of degree granting Catholic colleges as of 1911, 1951, 1971 and 2001 respectively. There is a small correlation in 1951, which grows over time. By 2001 there is a significant and positive correlation between the historical presence of Catholic

\footnotetext{
${ }^{25}$ Acemoglu at el (2014) use Protestant missionaries as an instrument for average levels of schooling and they also report a weak first stage in some models.
} 
missionaries and Catholic colleges. Taken together these findings suggest Catholic missionaries were uncorrelated with tertiary education historically. Their impact on current tertiary education operates through an increase in the supply of colleges beginning in the 1950s.

Although the historical presence of Catholic missionaries had no impact on historical tertiary education, Catholics missionaries may have influenced current income via alternative channels. We therefore carry out some rigorous checks on the validity of our exclusion restriction. Apart from education, Christian missionaries undertook other social activities like building hospitals and promoting better sanitation. Given the positive relationship between health, education and development, Catholic missionaries could influence current income by improving the health of the population. ${ }^{26}$ In Table 7 , column (1) we include infant mortality, our measure of health, as an additional control. The coefficient on tertiary education remains large and statistically significant. We also test for a direct relationship between infant mortality and the location of Catholic missionaries. First stage results for the effect of Catholic missionaries on alternative channels are displayed in Table A1 in the Appendix. Column (1) indicates the presence of missionaries in 1911 is not related to contemporaneous measures of health, suggesting the health mechanism is not a plausible channel through which Catholic missionaries have influenced current income.

The IV estimates on tertiary education could also be driven by general religiosity, which encourages attitudes of thrift, work ethic and honesty. For example, Nunn (2010) finds that descendants of populations that experienced greater missionary contact in colonial Africa are more likely to self-identify as Christians today. To assess this possibility, we control for the direct effect of religion by including the current population share of Christians as a control in column (2). While the current Christian share is negatively related to light density, the coefficient on tertiary education is unchanged. ${ }^{27}$

\footnotetext{
${ }^{26}$ Recent studies have analyzed the relationship between religion and health in India. Calvi and Mantovanelli (2014) find that proximity to a historical Protestant medical mission has a positive long-run effect on current health. They show that it is the proximity to a Protestant mission equipped with a medical facility that matters for current health and not the proximity to a generic Protestant mission. Using a broad set of instruments for Christian identity today, Menon (2015) finds that Christian infant girls score higher in terms of height for age than lower caste Hindu girls. In her first stage, however, the number of Catholic missions in 1910 is not statistically significant in any specification.

${ }^{27}$ The negative sign is perhaps because a larger proportion of disadvantaged groups such as the former lower castes and tribes were more likely to convert to Christianity in India. Our IV results on tertiary education are unchanged if we include the share of Christians in 1931 as a control.
} 
In column (3) we control for different measures of infrastructure because Catholic missionaries may have encouraged the construction of roads and irrigation facilities. Moreover, it may be the case that the expansion of government schooling has taken place in villages of districts where Catholic missionaries were located. If infrastructure is correlated with education and fosters development, the omission of infrastructure could bias the estimated coefficient. We include the propotion of villages with paved roads, the share of land that is irrigated, and government schools. We find that even after including these controls, tertiary education still has a positive and highly significant coefficient.

In column (4) we control for the share of migrants to the total population over 25 in the district. Although migration between states is not too widespread in India, we worry people may migrate in larger numbers to districts with a historical Catholic presence in pursuit of higher education or because these districts are more welcoming to outsiders. This would then bias our IV coefficient because the presence of Catholic missionaries may be impacting light density via higher migration rates. It is reassuring to see the coefficient on tertiary education is robust to controlling for migration.

Many studies suggest that institutions are the fundamental determinant of long-run income (Acemoglu et al, 2001, 2002). Given the potential correlation between institutions and human capital, Acemoglu et al. (2014) argue that human capital may capture some effects of institutions if the latter are not included in the analysis. In our analysis, the main source of institutional variation is across states. Since we include state fixed effects, the bias in the coefficient on human capital due to the omission of institutions in the set of controls is likely minimal. ${ }^{28}$ That said, we present a robustness exercise that account for past institutions. In Columns (5) and (6) we split the sample into Princely States and British India. There were fewer missionaries in Princely India and our regressions always include an indicator for Princely States. But, as shown in Iyer (2010), the British positively selected areas to bring under direct colonial control, i.e., British India. Thus, our IV results may be picking up heterogeneous differences between British India and the Princely States that are not captured in the simple indicator variable. Reassuringly, the split sample results find that the effect of tertiary education on luminosity holds in both samples.

\footnotetext{
${ }^{28}$ Reliable data for sub regional institutions are usually unavailable (Acemoglu et al, 2014). And, this is indeed the case for district-level data in India. Our results are robust to the inclusion of the banking infrastructure (number of banks: data from the Reserve Bank of India website) and crime rates (data from the National Crime Research Bureau).
} 
As mentioned earlier, St. Thomas Christians are an ancient Christian community that pre-date the arrival of Europeans. They are an important part of the Indian Catholic community and have set up many Catholic schools and colleges in Kerala where they are account for majority of the Catholic populations. Given their ancient lineage, one may be concerned the IV results are driven by Kerala and St. Thomas Christians. Hence, in Column (7), we drop the state of Kerala. Again, the results on tertiary education are essentially unchanged.

One last concern could be that there may still be alternative mechanisms through which Catholic missions could have affected current income that we are not accounting for. As a robustness exercise, we ran the following reduced form regression to asses the validity of our exclusion restriction:

$$
y_{d s}=\alpha+\sum \beta_{s} D_{s}+\lambda \text { Catholic } \text { Mission }_{d s}+\rho^{\prime} C_{d s}+\pi_{r}^{\prime} G_{d s}+\delta_{r}^{\prime} H_{d s}+\varepsilon_{d s}
$$

If the effect of Catholic missionaries on current development is mainly driven by its influence on tertiary education, we would expect that once we control for the level of tertiary education, the effect of Catholic missionaries disappears. The estimated coefficient of $\lambda$ in Table 8 in Panel $A$ ranges from 0.447 (s.e. $=0.073$ ), in the parsimonious specification, to 0.147 (s.e. $=0.063$ ) when all controls are accounted for. In all cases, the estimated coefficient of Catholic missionaries is highly significant. When we control for the share of population with tertiary education, results in Panel $B$ show that the coefficient on Catholic missionaries is not statistically significant in any specification.

\subsection{Further sensitivity checks}

In this last section, we explore different proxies for development. In Table 9, we present IV estimates for another measure of development. The literature analyzing district-level development in India has been scarce due to the lack of good data on GDP per capita. Other scholars have used agricultural investment, agricultural productivity and the stock of health and education infrastructure as proxies for economic prosperity (e.g. Banerjee and Iyer 2005; Iyer 2010). Our use of night light data as a district-level outcome is part of our contribution to this literature.

However, there is another measure of district-level GDP. Indicus analytics, a research firm based in Delhi, has estimated GDP per-capita at the district level using expenditure 
and savings habits of households, characteristics and occupations. ${ }^{29}$ The correlation between night satellite data and Indicus GDP for the same year is 0.57. In columns (1) to (4), we study the relationship between current tertiary education and the Indicus measure of local GDP per-capita (total and by sector.) We find that higher tertiary education leads to higher GDP per-capita with the effect primarily operating through income in the service sector. The coefficient on tertiary education is small and statistically insignificant for agriculture and industry sector GDP per-capita. In theory, missionaries could have transferred the technology from their countries of origin. And, the use of more advanced irrigation techniques or fertilizers could directly affect development by increasing agricultural productivity in the districts where missionaries located. Likewise, missionaries could have promoted the skills of the people in manual work and could have created the basis for development in the industry sector. The insignificant results in columns (2) and (3) suggest this was not the case. The result in column (4) on service sector GDP is consistent with previous findings by Castelló-Climent and Mukhopadhyay (2013), who show a large effect of tertiary education on the growth of the service sector.

Finally, we check the robustness of the results to the presence of outliers. As our results could be driven by atypical observartions or extreme values, we drop districts with light density above the $99^{\text {th }}$ percentile and below the $1^{\text {st }}$ percentile, we exclude districts that contain the largest city in the state, districts with cities above one million population, and districts that have the state capital. We also check whether one particular state may be responsible for the results by dropping one state at a time. In all these specifications, the coefficient on tertiary education remains positive and statistically significant. ${ }^{30}$

\section{Conclusion}

This paper investigates if higher levels of education lead to higher levels of development. The literature has studied this question extensively but has failed to draw strong conclusions because the evidence so far is mixed. Many studies suffer for identification problems such as reverse causality and omitted variables. For example, as richer and faster grow-

\footnotetext{
${ }^{29}$ Indicus uses survey data from NSSO surveys, National Data Survey of Savings Patterns of Indians (NDSPPI), District Level Household Survey, Census of India, RBI dataset and other sources. The quality of the data computed by Indicus, however, is under debate. See, for example, the concerns about the data raised by Himanshu (2009) and the reply by Bhandari (2009).

${ }^{30}$ Results are available upon request.
} 
ing economies have more resources to invest in education, the direction of causality can go from development to education (Bils and Klenow, 2000). ${ }^{31}$ Moreover, education can also be correlated with omitted variables that influence development. The solution to the problem is not trivial as we need to find an exogenous source of variation in education.

We turn to history to address this problem. In line with the empirical literature that looks at history to identify the causal impact of institutions on development (see Acemoglu et al, 2000, 2001), we address the endogeneity of education by exploiting the location of Catholic missionaries in colonial India. Christian missionaries in general, and Catholic missionaries in particular are identified with high quality education around the world. However, the novelty of our identification strategy is to focus on India, a country where Christians form a small minority and have relatively limited influence over other institutions that lead to development. Further, we use district level data with state fixed effects to control for institutions and cultural characteristics. We also focus on a particular level of education as an attempt to identify the effect of education on development. Specifically, we propose a novel instrument for the share of population with tertiary education. This level of education is particularly important in the Indian context as it has been shown to be the main educational variable that is highly correlated to economic growth at the state level (see Castelló-Climent and Mukhopadhyay, 2013). ${ }^{32}$ The focus on one country and a particular level of education is therefore part of our strategy to better identify the causal effect of education of development.

We find that exposure to Catholic missionaries at the beginning of the $20^{\text {th }}$ century has had a long-term impact on the current composition of education. Our identification strategy relies on the fact that Catholic missionaries were not actively involved in the provision of education in the colonial period. The number of colleges and schools are uncorrelated with the presence of Catholic missionaries in 1911. In fact, we do not find evidence that Catholic missionaries located in richer or more educated places. Nevertheless, the historical missionaries network was a natural platform from where Catholics expanded high

\footnotetext{
${ }^{31}$ Bils and Klenow (2000) point out that the empirical literature has documents correlations but has not identified the direction of causation. Using calibration techniques, they argue the positive correlation between education and growth can be explained by a channel that goes from expected growth to schooling.

${ }^{32}$ Most of the literature has used average years of schooling to asses their effect on development and growth. However, average years of schooling is a broad measure of education and cannot disentagle the differential effects of each level of schooling. Other things being equal, an increment in average years of schooling in two countries may have different effects on development if the increment is driven by increases in primary, secondary or tertiary education (see Aghion et al, 2009).
} 
quality colleges after independence. Using the location of Catholic missionaries in 1911 as an exogenous source of variation in levels of higher education, we find a strong causal effect of a higher share of the population with tertiary education on contemporaneous levels of development, as measured by night light satellite data. The magnitude of the effect is sizeable; a standard deviation increase in tertiary education raises log light density by 0.39 , an economic effect of $9 \%$ given mean light density.

A broad array of sensitivity analyses indicate that it is implausible that Catholic missionaries have influenced current development through channels other than tertiary education. We also show the results hold with a rich set of geographical, historical and current controls. Further analyses indicate the effect of tertiary education on development is not driven by lower levels of education. Finally, results hold with alternative measures of development, and are not driven by atypical observations.

\section{References}

[1] Acemoglu, D. and M. Dell (2010). "Productivity Differences Between and Within Countries," American Economic Journal: Macroeconomics, Vol. 2(1), pp. 169-88.

[2] Acemoglu, D., F. A. Gallego y J. A. Robinson (2014). "Institutions, Human Capital and Development," NBER Working Paper No 19933.

[3] Acemoglu, D., S. Johnson and J. A. Robinson (2001). "The Colonial Origins of Comparative Development: An Empirical Investigation," American Economic Review, 91, 1369-1401.

[4] Acemoglu, D., S. Johnson and J. A. Robinson (2002). "Reversal of Fortune: Geography and Institutions in the Making of the Modern World Income Distribution," Quarterly Journal of Economics, 118, 1231-1294.

[5] Acemoglu, D., and S. Johnson (2007). "Disease and Development: The Effect of Life Expectancy on Economic Growth." Journal of Political Economy, Vol. 115 (6), pp. $925-85$.

[6] Alesina, A., S. Michalopoulos and E. Papaioannou (2012). "Ethnic Inequality," NBER Working Paper $\mathrm{N}^{o} 18512$. 
[7] Angrist, J. D. and J-S. Pischke (2009). "Mostly Harmless Econometrics," Princeton Univesity Press.

[8] Ashraf, Q. and O. Galor (2013). "The 'Out-of-Africa' Hypothesis, Human Genetic Diversity, and Comparative Economic Development." American Economic Review, Vol. 103 (1), pp. 1-46.

[9] Banerjee, A. and L. Iyer (2005) "History, Institutions and Economic Performance: the Legacy of Colonial Land Tenure Systems in India" American Economic Review, Vol. 95(4), pp. 1190-213.

[10] Becker, S. O. and L. Woessmann (2008). "Luther and the Girls: Religious Denomination and the Female Education Gap in Nineteenth-century Prussia," Scandinavian Journal of Economics, Vol. 110(4), pp. 777-805.

[11] Becker, S. O. and L. Woessmann (2009). "Was Weber Wrong? A Human Capital Theory of Protestant Economic History," Quarterly Journal of Economics, Vol. 124(2), pp. 531-596.

[12] Benhabib, J. and M. Spiegel (1994). "The Role of Human Capital in Economic Development." Journal of Monetary Economics, 34 (2), pp. 143-174.

[13] Besley, T. and R. Burgess (2000). "Land Reform, poverty Reduction, and Growth: evidence from India," Quarterly Journal of Economics, 115(2), pp. 389-430.

[14] Bharadwaj, P., A. Khwaja and A. Mian (2008). "The Big March: Migratory Flows after the Partition of India." Economic and Political Weekly Vol. 43, No. 35, 39-49.

[15] Bloom, David E., David Canning and Jaypee Sevilla (2004), "The Effect of Health on Economic Growth: A Production Function Approach", World Development Vol. 32, no. 1, pp. 1-13.

[16] Calvi, R. and F. Mantovanelli (2014). "Long-Term Effects of Access to Health Care: Medical missionaries in Colonial India" Mimeo Boston College.

[17] Cameron, A.C., J. Gelbach and D. Miller (2008). "Bootstrap-Based Improvements for Inference with Clustered Errors," Review of Economics and Statistics, Vol. 90, pp. $414-27$. 
[18] Card, D. (2001). "Estimating the Return to Schooling: Progress on Some Persistent Econometric Problems," Econometrica, Vol. 69(5), pp. 1127-60.

[19] Castelló-Climent, A. and A. Mukhopadhyay (2013). "Mass Education or a Minority Well Educated Elite in the Process of Growth: the Case of India," Journal of Development Economics, Vol. 105, pp. 303-320.

[20] Cohen, D. and M. Soto (2007). "Growth and Human Capital: Good Data, Good Results," Journal of Economic Growth, Vol. 12, pp. 51-76.

[21] Comin, D., W. Easterly, and E. Gong (2010). "Was the Wealth of Nations Determined in 1000 BC?" American Economic Journal: Macroeconomics, Vol.. 2 (3), pp. 65-97.

[22] Catholic Students' Mission Crusade (CSMC) (1923). India and its missionaries. New York: Macmillan.

[23] Codina, G. S.J. (2000). "A Century of Jesuit Education, 1900-2000," in Jesuits: Yearbook of the Society of Jesus.

[24] Chaudhary, L. (2015). "Caste, Colonialism and Schooling: Education in British India." in Latika Chaudhary, Bishnupriya Gupta, Tirthankar Roy and Anand Swamy eds., A New Economic History of India. London: Routledge.

[25] Chaudhury, N., J. Hammer, M. Kremer, K. Muralidharan, and F. H. Rogers (2006). "Missing in Action: Teacher and Health Worker Absence in Developing Countries." Journal of Economic Perspectives, Vol. 20(1), pp. 91-116.

[26] Chen, X. and W. D. Nordhaus (2010). "The Value of Luminosity Data as a Proxy for Economic Statistics." NBER Working Papers No 16.317.

[27] De la Fuente, A. and R. Doménech (2006). "Human Capital in Growth Regressions: How Much Difference Does Data Quality Make?," Journal of the European Economic Association, 4(1), pp. 1-36.

[28] Easterly, W. and R. Levine (2012). "The European Origins of Economic Development," NBER Working Paper No 18162.

[29] Engerman, S. L., and K. Sokoloff (2000). "Institutions, Factor Endowments, and Paths of Development in the New World," Journal of Economic Perspectives, Vol. XIV, pp. 217-32. 
[30] Frankel, J. A. and D. Romer (1999). "Does Trade Cause Growth?" American Economic Review, Vol. 89(3), pp. 379-399.

[31] Frykenberg, R. E. (2008). "Christianity in India: From Beginnings to the Present," Oxford University Press.

[32] Gallego, F. A. and R. D. Woodberry (2010). "Christian Missionaries and Education in Former African Colonies: How Competition Mattered," Journal of African Economies, Vol. 19(3), pp. 294-329.

[33] Gennaioli, N., R. La Porta, F. Lopez-de-Silanes, A. Shleifer (2013). "Human Capital and Regional Development," Quarterly Journal of Economics, Vol. 128(1), pp. 10564 .

[34] Glaeser, E. L., R. La Porta, F. Lopezde-Silanes, and A. Shleifer (2004). "Do Institutions Cause Growth?" Journal of Economic Growth, Vol. 9 (3), pp. 271-303.

[35] Henderson, J. V., A. Storeygard and D. N. Weil (2012). "Measuring Economic Growth from Outer Space." American Economic Review, Vol. 102(2), pp. 994-1028.

[36] Huizinga, H. (1909) Missionary Education in India. Cuttack: [Printed at the Orissa Mission Press (by E.W. Warburton) for the author.

[37] Iyer, L. (2010). "Direct versus Indirect Colonial Rule in India: Long-term Consequences," Review of Economics and Statistics, Vol. 92(4), pp. 693-713.

[38] Kumar, H. and R. Somanathan (2009). "Mapping Indian Districts Across Census Years, 1971-2001," Economic and Political Weekly, Vol. 36(9), pp. 783-92.

[39] Lorentzen, P., J. McMillan, and R. Wacziarg (2008). "Death and Development." Journal of Economic Growth, Vol. 13 (2), pp. 81-124.

[40] Lucas, R. (1988). "On the Mechanics of Economic Development," Journal of Monetary Economics, Vol. 22, pp. 3-42.

[41] Mantovanelli, F. G. (2014). "The Protestant Legacy: missionaries and Literacy in India," Mimeo Boston College.

[42] Menon, N. (2015). "Christianity and Infant Health in India," IZA DP No 9177. 
[43] Michalopoulos, S. and E. Papaioannou (2013) "Pre-colonial Ethnic Institutions and Contemporary African Development," Econometrica, Vol. 81(1), pp. 113-52.

[44] Michalopoulos, S. and E. Papaioannou (2014) "National Institutions and Subnational Development in Africa," Quarterly Journal of Economics, pp. 151-213.

[45] Munshi, K. and M. Rosenzweig (2009) "Why is Mobility in India so Low? Social Insurance, Inequality, and Growth," NBER Working Papers 14850, National Bureau of Economic Research, Inc.

[46] North, D. C. (1990). "Institutions, Institutional Change and Economic Performance." Cambridge; New York and Melbourne: Cambridge University Press.

[47] Nunn, N. (2010). "Religious Conversion in Colonial Africa," American Economic Review Papers and Proceedings, Vol. 100 (2), pp. 147-52.

[48] Nunn, N. (2014). "Gender and Missionary Influence in Colonial Africa," in Emmanuel Akyeampong, Robert Bates, Nathan Nunn and James A. Robinson (eds.), Africa's Development in Historical Perspective, Chapter 16, pp. 489-512. Cambridge University Press, 2014.

[49] Nunn, N. (2014). "Historical Development," Handbook of Economic Growth, Chapter Seven, Vol. 2A, pp. 347-402.

[50] Pinkovskiy, M. L. (2013). "Economic Discontinuities at Borders: Evidence from Satellite Data on Lights at Night" Mimeo, Federal Reserve Bank of New York.

[51] Pritchett, L. (2001). "Where Has All the Education Gone," World Bank Economic Review, Vol. 15(3), pp. 367-91.

[52] Putterman, L., and D. N. Weil (2010). "Post-1500 Population Flows and the LongRun Determinants of Economic Growth and Inequality." Quarterly Journal of Economics, Vol. 125 (4), pp. 1627-82.

[53] Richter, J. (1908). A history of missionaries in India. Edinburgh: Oliphant.

[54] Sachs, J. (2003), "Institutions don't rule: Direct Effects of Geography on Per Capita Income" NBER Working Papers 9490, National Bureau of Economic Research, Inc. 
[55] Sokoloff, K. L., and S. L. Engerman (2000). "Institutions, Factor Endowments, and Paths of Development in the New World." Journal of Economic Perspectives, Vol. 14 (3), pp. 217-32.

[56] Spolaore, E. and R. Wacziarg (2013). "How Deep Are the Roots of Economic Development?," Journal of Economic Literature, Vol. 51(2), pp. 325-69.

[57] Stock J.H. and M. Yogo (2005). "Testing for Weak Instruments in Linear IV Regression," In Andrews DWK Identification and Inference for Econometric Models. New York: Cambridge University Press, pp. 80-108.

[58] Vandenbussche, J., P. Aghion and C. Meghir (2006). "Growth, Distance to Frontier and Composition of Human Capital." Journal of Economic Growth,11, pp. 97-127. 
Table 1: Summary Statistics

\begin{tabular}{lccccc}
\hline \hline Variables & Obs & Mean & Std. Dev. & Min & Max \\
\hline Current & & & & & \\
Log Light Density & 500 & 4.240 & 1.092 & -0.953 & 6.407 \\
Log GDP per-Capita & 498 & -3.924 & .54 & -5.482 & -1.914 \\
Share Tertiary (25+) & 500 & .058 & .03 & .014 & .213 \\
Share Secondary (25+) & 500 & .339 & .097 & .115 & .664 \\
Share SC & 500 & .162 & .079 & 0 & .501 \\
Share ST & 500 & .11 & .177 & 0 & .938 \\
Pop 25+ & 500 & 874,426 & 613,867 & 41,358 & $4,670,683$ \\
& & & & & \\
Geography & & & & & \\
Coastal & 500 & .098 & .298 & 0 & 1 \\
Longitude & 500 & 79.793 & 5.073 & 69.778 & 95.627 \\
Latitude & 500 & 23.108 & 5.907 & 8.308 & 34.534 \\
Av. River Length & 500 & 12.156 & 3.737 & 2.932 & 30.342 \\
Min Dist Big City & 500 & 336.522 & 181.811 & 3.563 & 947.762 \\
Av. Height & 500 & 403.836 & 619.58 & 3.967 & 4941.724 \\
& & & & & \\
Historical & & & & & \\
Catholic Missionary & 500 & .3 & .459 & 0 & 1 \\
Protestant Mission & 500 & .582 & .494 & 0 & 1 \\
Share Urban, 1931 & 500 & .107 & .08 & 0 & .50 \\
Share Brahman, 1931 & 500 & .056 & .043 & 0 & .27 \\
Share Tribal, 1931 & 500 & .034 & .088 & 0 & .69 \\
Princely State & 500 & .34 & .474 & 0 & 1 \\
Railway Line, 1909 & 500 & .782 & .413 & 0 & 1 \\
& & & & & \\
\hline & & & & &
\end{tabular}


Table 2: OLS Results - Log Light Density

\begin{tabular}{|c|c|c|c|c|c|}
\hline & $(1)$ & $(2)$ & $(3)$ & $(4)$ & $(5)$ \\
\hline Share Tertiary & $\begin{array}{c}14.396^{* * *} \\
(1.136)\end{array}$ & $\begin{array}{c}11.203^{* * *} \\
(1.176)\end{array}$ & $\begin{array}{c}10.638 * * * \\
(0.921)\end{array}$ & $\begin{array}{c}9.871^{* * *} \\
(0.965)\end{array}$ & $\begin{array}{c}8.019^{* * *} \\
(1.077)\end{array}$ \\
\hline Share Secondary & & & & & $\begin{array}{c}1.317^{* * *} \\
(0.506)\end{array}$ \\
\hline Share SC & & $\begin{array}{l}-0.045 \\
(0.687)\end{array}$ & $\begin{array}{l}-0.405 \\
(0.499)\end{array}$ & $\begin{array}{l}-0.623 \\
(0.490)\end{array}$ & $\begin{array}{l}-0.737 \\
(0.477)\end{array}$ \\
\hline Share ST & & $\begin{array}{c}-2.109^{* * *} \\
(0.319)\end{array}$ & $\begin{array}{c}-1.638^{* * *} \\
(0.219)\end{array}$ & $\begin{array}{c}-1.445^{* * *} \\
(0.228)\end{array}$ & $\begin{array}{c}-1.358^{* * *} \\
(0.245)\end{array}$ \\
\hline Pop 25+ & & $\begin{array}{c}0.000^{* * *} \\
(0.000)\end{array}$ & $\begin{array}{l}0.000^{*} \\
(0.000)\end{array}$ & $\begin{array}{c}0.000 \\
(0.000)\end{array}$ & $\begin{array}{c}0.000 \\
(0.000)\end{array}$ \\
\hline Coastal & & & $\begin{array}{c}-0.131^{*} \\
(0.072)\end{array}$ & $\begin{array}{c}-0.187^{* * *} \\
(0.070)\end{array}$ & $\begin{array}{c}-0.233^{* * *} \\
(0.074)\end{array}$ \\
\hline Long & & & $\begin{array}{l}0.038^{*} \\
(0.022)\end{array}$ & $\begin{array}{c}0.044^{* *} \\
(0.022)\end{array}$ & $\begin{array}{l}0.039 * \\
(0.022)\end{array}$ \\
\hline Lat & & & $\begin{array}{c}0.009 \\
(0.020)\end{array}$ & $\begin{array}{l}-0.006 \\
(0.019)\end{array}$ & $\begin{array}{c}0.000 \\
(0.019)\end{array}$ \\
\hline Av. River Length & & & $\begin{array}{c}0.013 \\
(0.008)\end{array}$ & $\begin{array}{c}0.012 \\
(0.008)\end{array}$ & $\begin{array}{c}0.011 \\
(0.008)\end{array}$ \\
\hline Min Dist Big City & & & $\begin{array}{c}-0.001^{* * *} \\
(0.000)\end{array}$ & $\begin{array}{c}-0.001^{* * *} \\
(0.000)\end{array}$ & $\begin{array}{c}-0.001^{* * *} \\
(0.000)\end{array}$ \\
\hline Average Height & & & $\begin{array}{c}-0.001^{* * *} \\
(0.000)\end{array}$ & $\begin{array}{c}-0.001^{* * *} \\
(0.000)\end{array}$ & $\begin{array}{c}-0.001^{* * * *} \\
(0.000)\end{array}$ \\
\hline Share Urban (1931) & & & & $\begin{array}{c}0.532 \\
(0.464)\end{array}$ & $\begin{array}{c}0.492 \\
(0.454)\end{array}$ \\
\hline Share Brahmin (1931) & & & & $\begin{array}{l}-0.100 \\
(0.958)\end{array}$ & $\begin{array}{l}-0.532 \\
(0.976)\end{array}$ \\
\hline Share Tribal (1931) & & & & $\begin{array}{c}-0.843^{*} \\
(0.481)\end{array}$ & $\begin{array}{c}-0.815^{*} \\
(0.470)\end{array}$ \\
\hline Princely State & & & & $\begin{array}{l}-0.050 \\
(0.059)\end{array}$ & $\begin{array}{l}-0.005 \\
(0.063)\end{array}$ \\
\hline Railway Line, 1909 & & & & $\begin{array}{c}0.264^{* * *} \\
(0.071)\end{array}$ & $\begin{array}{c}0.254^{* * *} \\
(0.072)\end{array}$ \\
\hline Constant & $\begin{array}{c}1.891^{* * *} \\
(0.473)\end{array}$ & $\begin{array}{c}2.476^{* * *} \\
(0.364)\end{array}$ & $\begin{array}{c}2.050 \\
(1.576)\end{array}$ & $\begin{array}{c}1.991 \\
(1.578)\end{array}$ & $\begin{array}{c}1.741 \\
(1.585)\end{array}$ \\
\hline Observations & 500 & 500 & 500 & 500 & 500 \\
\hline R-squared & 0.624 & 0.705 & 0.793 & 0.804 & 0.807 \\
\hline State FE & YES & YES & YES & YES & YES \\
\hline
\end{tabular}


Table 3A: Selection of Catholic Missionary Location?

\begin{tabular}{|c|c|c|c|}
\hline & $(1)$ & $(2)$ & $(3)$ \\
\hline Coastal & $\begin{array}{c}0.314^{* * *} \\
(0.079)\end{array}$ & $\begin{array}{c}0.345^{* * *} \\
(0.110)\end{array}$ & $\begin{array}{r}0.269^{* *} \\
(0.118)\end{array}$ \\
\hline Long & $\begin{array}{c}-0.029^{* *} \\
(0.013)\end{array}$ & $\begin{array}{c}0.003 \\
(0.038)\end{array}$ & $\begin{array}{l}-0.031 \\
(0.046)\end{array}$ \\
\hline Lat & $\begin{array}{l}-0.028^{*} \\
(0.015)\end{array}$ & $\begin{array}{l}-0.003 \\
(0.039)\end{array}$ & $\begin{array}{c}0.052 \\
(0.047)\end{array}$ \\
\hline Av. River Length & $\begin{array}{l}-0.007 \\
(0.005)\end{array}$ & $\begin{array}{c}0.011 \\
(0.013)\end{array}$ & $\begin{array}{c}0.003 \\
(0.014)\end{array}$ \\
\hline Min Dist Big City & $\begin{array}{l}-0.000 \\
(0.000)\end{array}$ & $\begin{array}{l}-0.000 \\
(0.000)\end{array}$ & $\begin{array}{l}-0.001 \\
(0.000)\end{array}$ \\
\hline Average Height & $\begin{array}{l}0.000^{*} \\
(0.000)\end{array}$ & $\begin{array}{c}0.001^{* * *} \\
(0.000)\end{array}$ & $\begin{array}{c}0.000 \\
(0.000)\end{array}$ \\
\hline Railway Line, 1909 & $\begin{array}{c}0.257^{* * *} \\
(0.043)\end{array}$ & $\begin{array}{c}0.287^{* * *} \\
(0.102)\end{array}$ & $\begin{array}{l}0.258^{* *} \\
(0.112)\end{array}$ \\
\hline Share Urban, 1901 & & & $\begin{array}{c}1.739 \\
(1.094)\end{array}$ \\
\hline Share Brahman, 1901 & & & $\begin{array}{c}2.493 \\
(2.103)\end{array}$ \\
\hline Share Lower Castes, 1901 & & & $\begin{array}{l}-0.399 \\
(0.639)\end{array}$ \\
\hline Share Tribes, 1901 & & & $\begin{array}{l}1.048^{*} \\
(0.558)\end{array}$ \\
\hline Ethnic Frac, 1901 & & & $\begin{array}{l}-0.249 \\
(0.611)\end{array}$ \\
\hline Pop, 1901 & & & $\begin{array}{c}0.000 \\
(0.000)\end{array}$ \\
\hline Income-Tax per Capita, 1901 & & & $\begin{array}{c}0.771 \\
(1.193)\end{array}$ \\
\hline Colleges, 1901 & & & $\begin{array}{l}-0.020^{*} \\
(0.011)\end{array}$ \\
\hline Schools, 1901 & & & $\begin{array}{c}0.000 \\
(0.000)\end{array}$ \\
\hline Constant & $\begin{array}{c}3.115^{* * *} \\
(1.047)\end{array}$ & $\begin{array}{l}-0.367 \\
(2.391)\end{array}$ & $\begin{array}{c}0.828 \\
(3.138)\end{array}$ \\
\hline $\begin{array}{l}\text { Observations } \\
R^{2}\end{array}$ & $\begin{array}{c}500 \\
0.297\end{array}$ & $\begin{array}{c}156 \\
0.360\end{array}$ & $\begin{array}{c}156 \\
0.408\end{array}$ \\
\hline
\end{tabular}

State FE are included. Robust standard errors in parentheses *** $\mathrm{p}<0.01,{ }^{* *} \mathrm{p}<0.05,{ }^{*} \mathrm{p}<0.1$ 
Table 3B: Selection of Protestant Missionary Location?

\begin{tabular}{|c|c|c|c|}
\hline & (1) & (2) & (3) \\
\hline Coastal & $\begin{array}{c}0.327^{* * *} \\
(0.052)\end{array}$ & $\begin{array}{c}0.394^{* * *} \\
(0.078)\end{array}$ & $\begin{array}{c}0.382^{* * *} \\
(0.086)\end{array}$ \\
\hline Long & $\begin{array}{l}-0.008 \\
(0.016)\end{array}$ & $\begin{array}{c}-0.054^{*} \\
(0.033)\end{array}$ & $\begin{array}{l}-0.018 \\
(0.041)\end{array}$ \\
\hline Lat & $\begin{array}{c}-0.033^{* *} \\
(0.016)\end{array}$ & $\begin{array}{c}0.006 \\
(0.030)\end{array}$ & $\begin{array}{l}-0.012 \\
(0.039)\end{array}$ \\
\hline Av. River Length & $\begin{array}{l}-0.003 \\
(0.006)\end{array}$ & $\begin{array}{c}0.008 \\
(0.011)\end{array}$ & $\begin{array}{c}0.004 \\
(0.012)\end{array}$ \\
\hline Min Dist Big City & $\begin{array}{c}0.000 \\
(0.000)\end{array}$ & $\begin{array}{c}0.000 \\
(0.000)\end{array}$ & $\begin{array}{c}0.000 \\
(0.000)\end{array}$ \\
\hline Average Height & $\begin{array}{l}0.000^{* *} \\
(0.000)\end{array}$ & $\begin{array}{c}0.000^{* *} \\
(0.000)\end{array}$ & $\begin{array}{c}0.000^{* *} \\
(0.000)\end{array}$ \\
\hline Railway Line, 1909 & $\begin{array}{c}0.212^{* * *} \\
(0.057)\end{array}$ & $\begin{array}{c}0.279^{* * *} \\
(0.090)\end{array}$ & $\begin{array}{c}0.268^{* * *} \\
(0.097)\end{array}$ \\
\hline Share Urban, 1901 & & & $\begin{array}{c}-1.834^{* *} \\
(0.899)\end{array}$ \\
\hline Share Brahman, 1901 & & & $\begin{array}{l}2.214 \\
(2.581)\end{array}$ \\
\hline Share Lower Castes, 1901 & & & $\begin{array}{c}0.092 \\
(0.495)\end{array}$ \\
\hline Share Tribes, 1901 & & & $\begin{array}{c}0.224 \\
(0.632)\end{array}$ \\
\hline Ethnic Frac, 1901 & & & $\begin{array}{c}0.996^{* *} \\
(0.485)\end{array}$ \\
\hline Pop, 1901 & & & $\begin{array}{c}0.000 \\
(0.000)\end{array}$ \\
\hline Income-Tax per Capita, 1901 & & & $\begin{array}{l}1.086 \\
(0.983)\end{array}$ \\
\hline Colleges, 1901 & & & $\begin{array}{l}-0.001 \\
(0.013)\end{array}$ \\
\hline Schools, 1901 & & & $\begin{array}{l}-0.000 \\
(0.000)\end{array}$ \\
\hline Constant & $\begin{array}{c}1.507 \\
(1.180)\end{array}$ & $\begin{array}{l}3.949^{*} \\
(2.020)\end{array}$ & $\begin{array}{l}1.161 \\
(2.605)\end{array}$ \\
\hline $\begin{array}{l}\text { Observations } \\
R^{2}\end{array}$ & $\begin{array}{c}500 \\
0.205\end{array}$ & $\begin{array}{c}156 \\
0.384\end{array}$ & $\begin{array}{c}156 \\
0.423\end{array}$ \\
\hline
\end{tabular}

State FE are included. Robust standard errors in parentheses *** $\mathrm{p}<0.01,{ }^{* *} \mathrm{p}<0.05,{ }^{*} \mathrm{p}<0.1$ 
Table 4: Instrumental Variables Results

\begin{tabular}{lccccc}
\hline \hline \multicolumn{1}{c}{$(1)$} & $(2)$ & $(3)$ & $(4)$ & $(5)$ \\
\hline \multicolumn{4}{c}{ Panel A: First Stage - Catholic Missionary } & on Tertiary Education \\
\hline \multirow{2}{*}{ Catholic Missionary } & $0.027^{* * *}$ & $0.018^{* * *}$ & $0.019^{* * *}$ & $0.015^{* * *}$ & $0.012^{* * *}$ \\
& $(0.004)$ & $(0.003)$ & $(0.003)$ & $(0.003)$ & $(0.003)$ \\
F-stat Excluded IV & & & & \\
Cragg-Donald Wald F-stat & 97.27 & 26.74 & 28.85 & 20.17 & 17.28 \\
& 90.19 & 37.73 & 40.37 & 28.07 & 16.16 \\
\hline
\end{tabular}

Panel B: Second Stage - Log Light Density

\begin{tabular}{lccccc}
\hline Share Tertiary & $\begin{array}{c}16.246^{* * *} \\
(2.264)\end{array}$ & $\begin{array}{c}14.232^{* * *} \\
(3.514)\end{array}$ & $\begin{array}{c}15.621^{* * *} \\
(3.089)\end{array}$ & $\begin{array}{c}12.968^{* * *} \\
(3.788)\end{array}$ & $\begin{array}{c}12.651^{* *} \\
(5.010)\end{array}$ \\
Observations & 500 & 500 & 500 & 500 & 500 \\
$R^{2}$ & 0.622 & 0.700 & 0.781 & 0.800 & 0.801 \\
& & & & \\
\hline Controls & & & & YES & YES \\
State FE & YES & YES & YES & YES & YES \\
Current & NO & YES & YES & YES & YES \\
Geographic & NO & NO & YES & YES & YES \\
Historical & NO & NO & NO & NO & YES \\
Schooling & NO & NO & NO & & \\
\hline
\end{tabular}

Robust standard errors in parentheses.

*** $\mathrm{p}<0.01,{ }^{*} * \mathrm{p}<0.05,{ }^{*} \mathrm{p}<0.1$ 
Table 5: Instrumental Variables Results for Tertiary and Other Schooling

\begin{tabular}{|c|c|c|c|c|}
\hline & $(1)$ & $(2)$ & $(3)$ & $(4)$ \\
\hline \multicolumn{5}{|c|}{ Panel A: First Stage - Christian Missionary on Tertiary Education } \\
\hline Catholic Missionary & $\begin{array}{c}0.025^{* * *} \\
(0.004)\end{array}$ & $\begin{array}{c}0.017^{* * *} \\
(0.003)\end{array}$ & $\begin{array}{c}0.018^{* * *} \\
(0.004)\end{array}$ & $\begin{array}{c}0.014^{* * *} \\
(0.003)\end{array}$ \\
\hline Protestant Missionary & $\begin{array}{l}0.005^{*} \\
(0.003)\end{array}$ & $\begin{array}{c}0.003 \\
(0.003)\end{array}$ & $\begin{array}{c}0.003 \\
(0.003)\end{array}$ & $\begin{array}{c}0.003 \\
(0.003)\end{array}$ \\
\hline
\end{tabular}

Panel B: First Stage - Christian Missionary on Other Schooling

\begin{tabular}{lcccc}
\hline Catholic Missionary & $\begin{array}{c}0.034^{* * *} \\
(0.008)\end{array}$ & $\begin{array}{c}0.023^{* * *} \\
(0.008)\end{array}$ & $\begin{array}{c}0.022^{* * *} \\
(0.008)\end{array}$ & $\begin{array}{c}0.014^{*} \\
(0.008)\end{array}$ \\
Protestant Missionary & $\begin{array}{c}0.016^{* *} \\
(0.007)\end{array}$ & $\begin{array}{c}0.017^{* *} \\
(0.007)\end{array}$ & $\begin{array}{c}0.015^{* *} \\
(0.007)\end{array}$ & $\begin{array}{c}0.013^{*} \\
(0.007)\end{array}$ \\
\hline & & & & \\
\hline & & & 3.82 & 2.49 \\
F-stat Excluded IV & 2.14 & 4.83 & 1.756 & 1.192 \\
\hline
\end{tabular}

Panel C: Second Stage - Log Light Density

\begin{tabular}{|c|c|c|c|c|}
\hline Share Tertiary & $\begin{array}{c}36.846 \\
(22.896)\end{array}$ & $\begin{array}{c}21.984^{* *} \\
(11.143)\end{array}$ & $\begin{array}{c}16.084^{*} \\
(9.262)\end{array}$ & $\begin{array}{l}13.217^{\mathrm{a}} \\
(9.331)\end{array}$ \\
\hline Share Schooling & $\begin{array}{l}-13.734 \\
(14.686)\end{array}$ & $\begin{array}{l}-4.694 \\
(6.016)\end{array}$ & $\begin{array}{l}-0.315 \\
(5.484)\end{array}$ & $\begin{array}{l}-0.218 \\
(6.537)\end{array}$ \\
\hline $\begin{array}{l}\text { Observations } \\
R^{2}\end{array}$ & $\begin{array}{c}500 \\
-0.038\end{array}$ & $\begin{array}{c}500 \\
0.607\end{array}$ & $\begin{array}{c}500 \\
0.778\end{array}$ & $\begin{array}{c}500 \\
0.799\end{array}$ \\
\hline $\begin{array}{l}\text { Controls } \\
\text { State FE } \\
\text { Current } \\
\text { Geographic } \\
\text { Historical }\end{array}$ & $\begin{array}{l}\mathrm{YES} \\
\mathrm{NO} \\
\mathrm{NO} \\
\mathrm{NO}\end{array}$ & $\begin{array}{l}\text { YES } \\
\text { YES } \\
\mathrm{NO} \\
\mathrm{NO}\end{array}$ & $\begin{array}{l}\text { YES } \\
\text { YES } \\
\text { YES } \\
\text { NO }\end{array}$ & $\begin{array}{l}\text { YES } \\
\text { YES } \\
\text { YES } \\
\text { YES }\end{array}$ \\
\hline
\end{tabular}




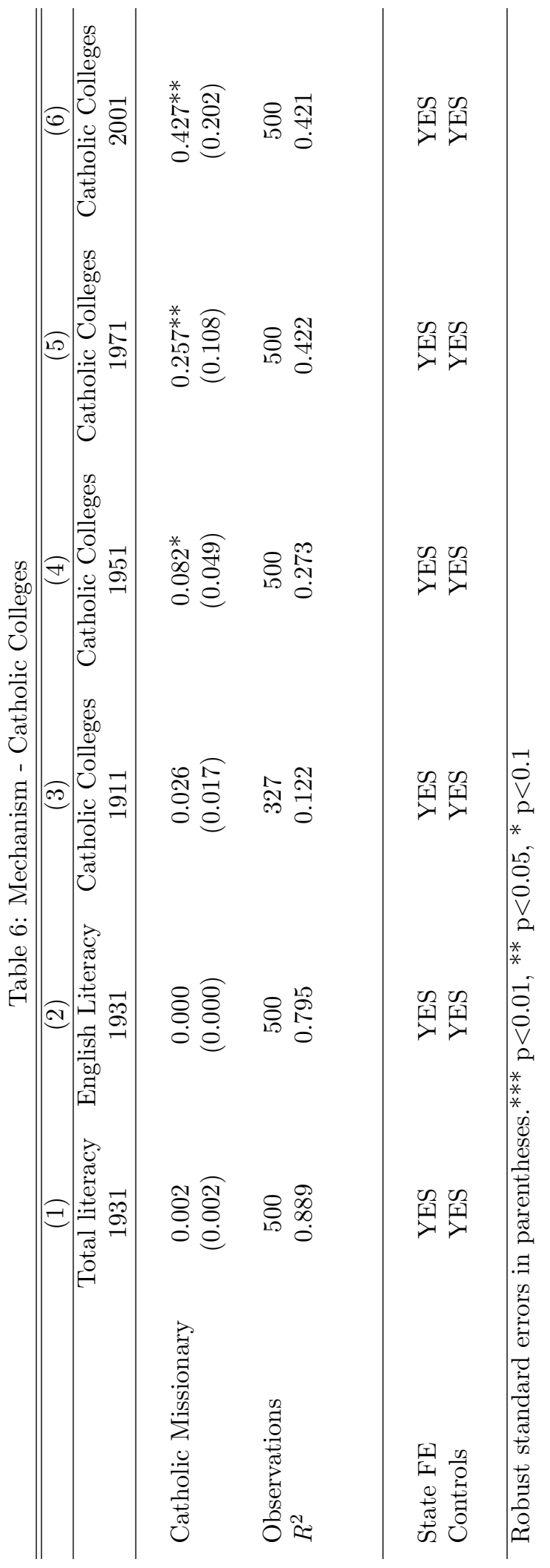




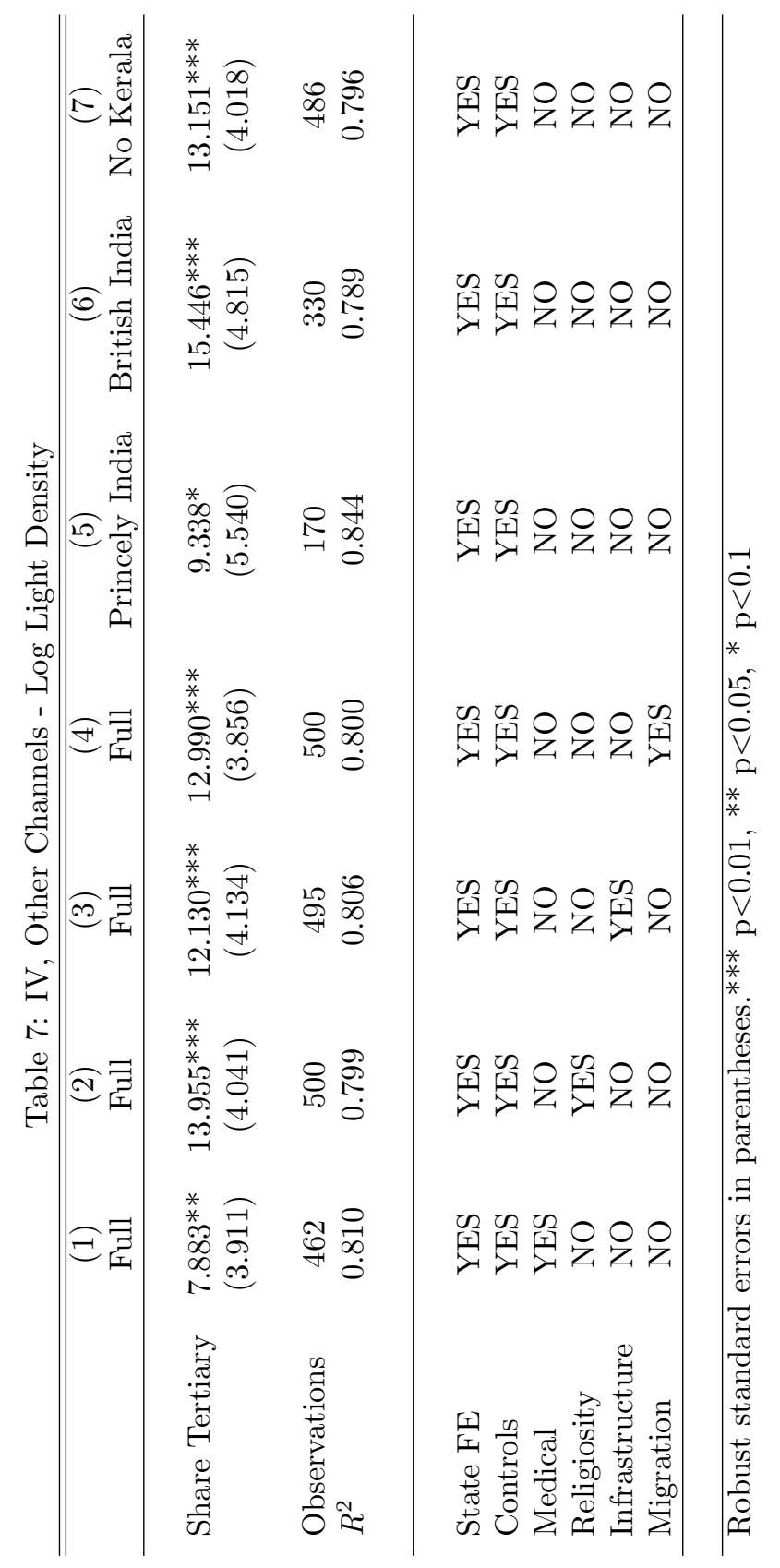


Table 8: Reduced Form IV Test

\begin{tabular}{|c|c|c|c|c|c|}
\hline & $(1)$ & $(2)$ & $(3)$ & $(4)$ & $(5)$ \\
\hline \multicolumn{6}{|c|}{ Panel A: OLS - Catholic Missionary on Log Light Density } \\
\hline Catholic Missionary & $\begin{array}{c}0.447^{* * *} \\
(0.073)\end{array}$ & $\begin{array}{c}0.254^{* * *} \\
(0.067)\end{array}$ & $\begin{array}{c}0.292^{* * *} \\
(0.062)\end{array}$ & $\begin{array}{c}0.200^{* * *} \\
(0.066)\end{array}$ & $\begin{array}{c}0.147^{* *} \\
(0.063)\end{array}$ \\
\hline Observations & 500 & 500 & 500 & 500 & 500 \\
\hline$R^{2}$ & 0.514 & 0.648 & 0.746 & 0.765 & 0.790 \\
\hline
\end{tabular}

Panel B: OLS - Catholic Missionary and Tertiary Education on Log Light Density

\begin{tabular}{lccccc} 
Share Tertiary & $14.048^{* * *}$ & $10.963^{* * *}$ & $10.210^{* * *}$ & $9.684^{* * *}$ & $7.793^{* * *}$ \\
Catholic Missionary & $(1.291)$ & $(1.242)$ & $(0.940)$ & $(0.986)$ & $(1.108)$ \\
& 0.060 & 0.058 & $0.101^{*}$ & 0.051 & 0.056 \\
& $(0.072)$ & $(0.066)$ & $(0.056)$ & $(0.060)$ & $(0.061)$ \\
Observations & 500 & 500 & 500 & 500 & 500 \\
$R^{2}$ & 0.624 & 0.705 & 0.794 & 0.804 & 0.808 \\
& & & & \\
\hline $\begin{array}{l}\text { Controls } \\
\text { State FE }\end{array}$ & YES & YES & YES & YES & YES \\
Current & NO & YES & YES & YES & YES \\
$\begin{array}{l}\text { Geographic } \\
\text { Historical }\end{array}$ & NO & NO & YES & YES & YES \\
Schooling & NO & NO & NO & YES & YES \\
& NO & NO & NO & NO & YES \\
\hline $\begin{array}{l}\text { Robust standard errors in parentheses. } \\
* * * \text { p }<0.01, * * \text { p }<0.05, * \text { p }<0.1\end{array}$ & & & & \\
\hline
\end{tabular}


Table 9: IV - GDP per-capita 2004, INDICUS

\begin{tabular}{lcccc}
\hline \hline & $(1)$ & $(2)$ & $(3)$ & $(4)$ \\
\hline & Total & Primary & Secondary & Tertiary \\
\hline Share Tertiary & $6.572^{* * *}$ & -2.181 & 2.568 & $16.195^{* * *}$ \\
& $(2.199)$ & $(3.471)$ & $(4.685)$ & $(2.286)$ \\
& & & & \\
Observations & 498 & 498 & 498 & 498 \\
R-squared & 0.734 & 0.433 & 0.586 & 0.825 \\
& & & & \\
\hline \multirow{2}{\text{StateFE}}{} & & & & \\
Controls & YES & YES & YES & YES \\
& & YES & YES & YES \\
\hline
\end{tabular}

Robust standard errors in parentheses.

${ }^{* * *} \mathrm{p}<0.01,{ }^{* *} \mathrm{p}<0.05,{ }^{*} \mathrm{p}<0.1$ 


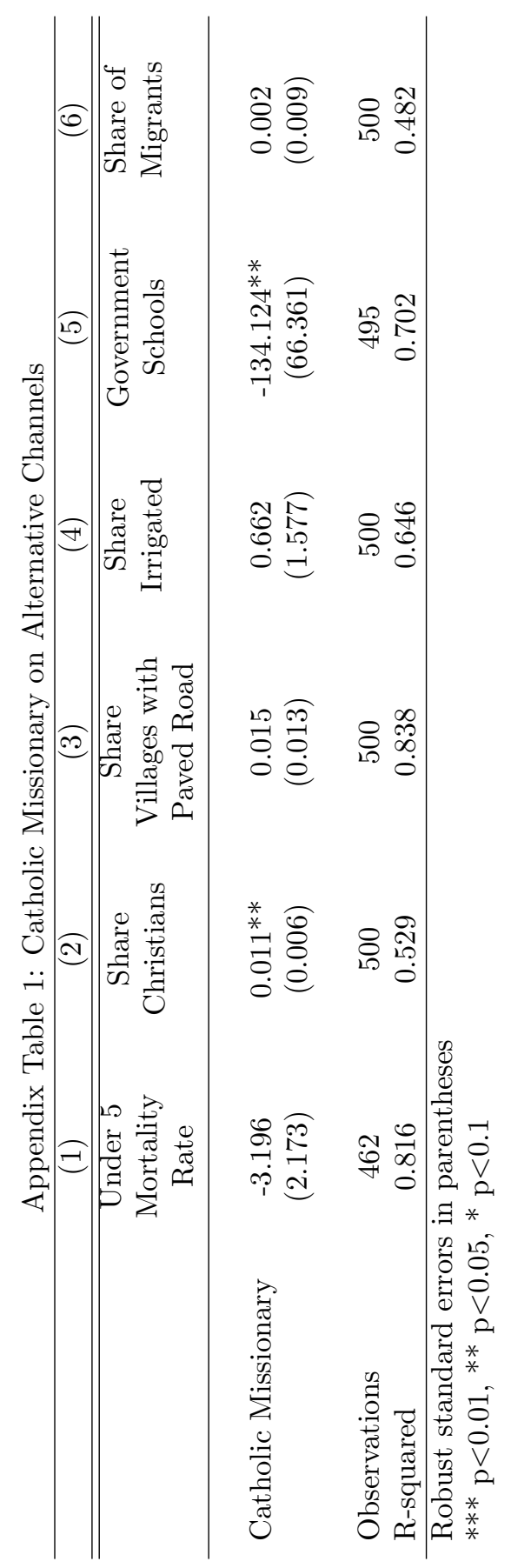




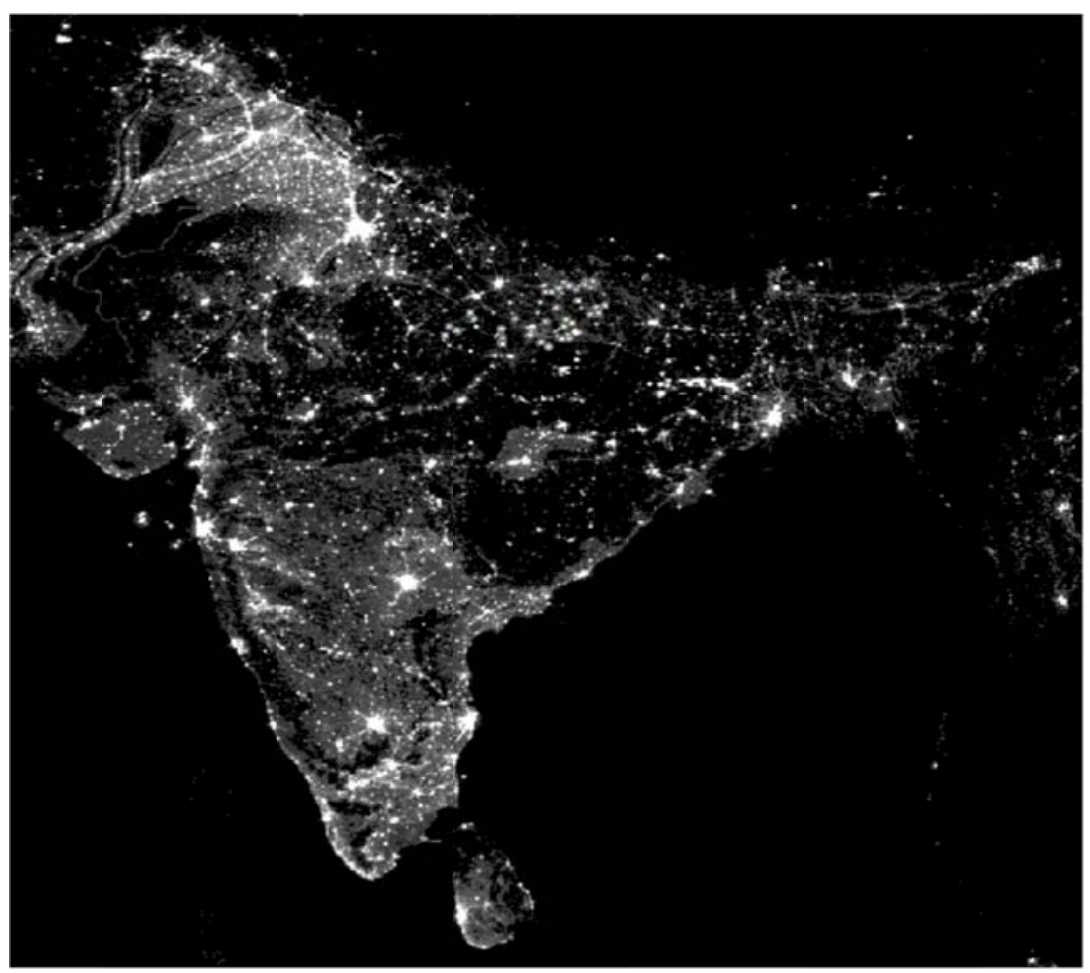

a- Night Lights Map

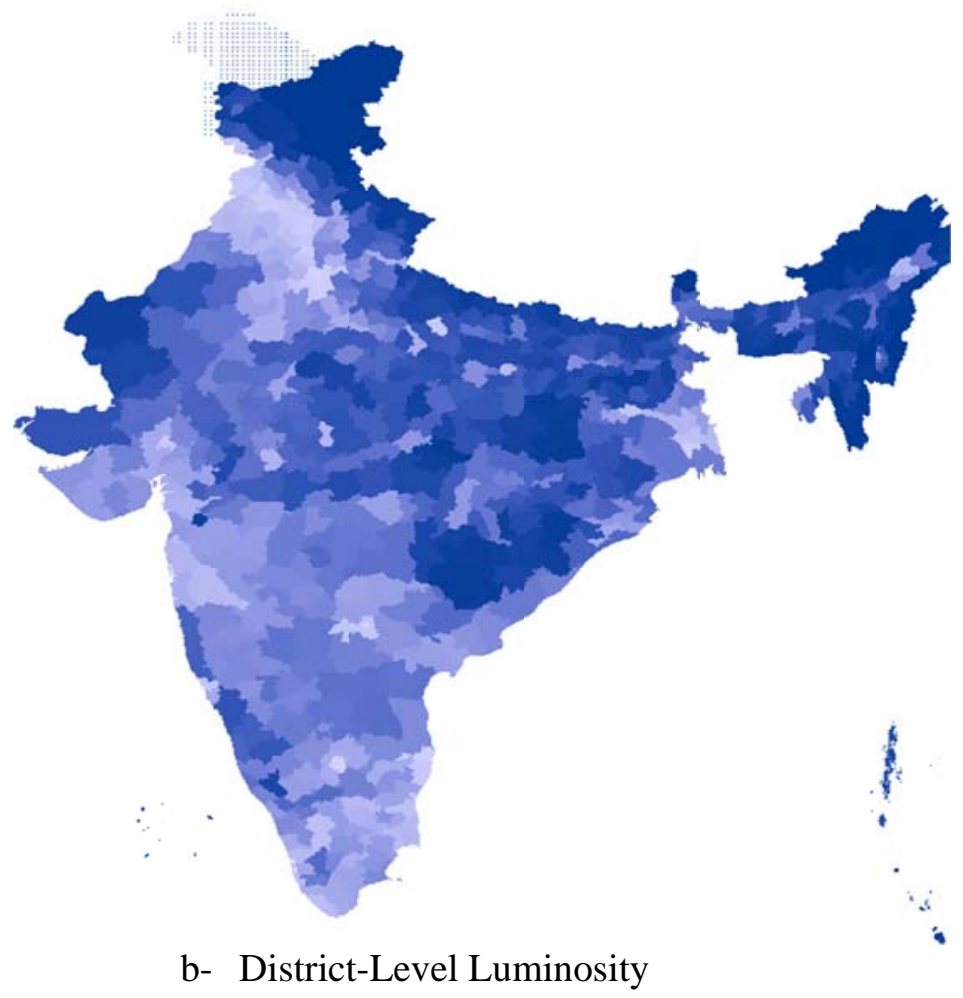

Figure 1- Lights at Night, 2006 


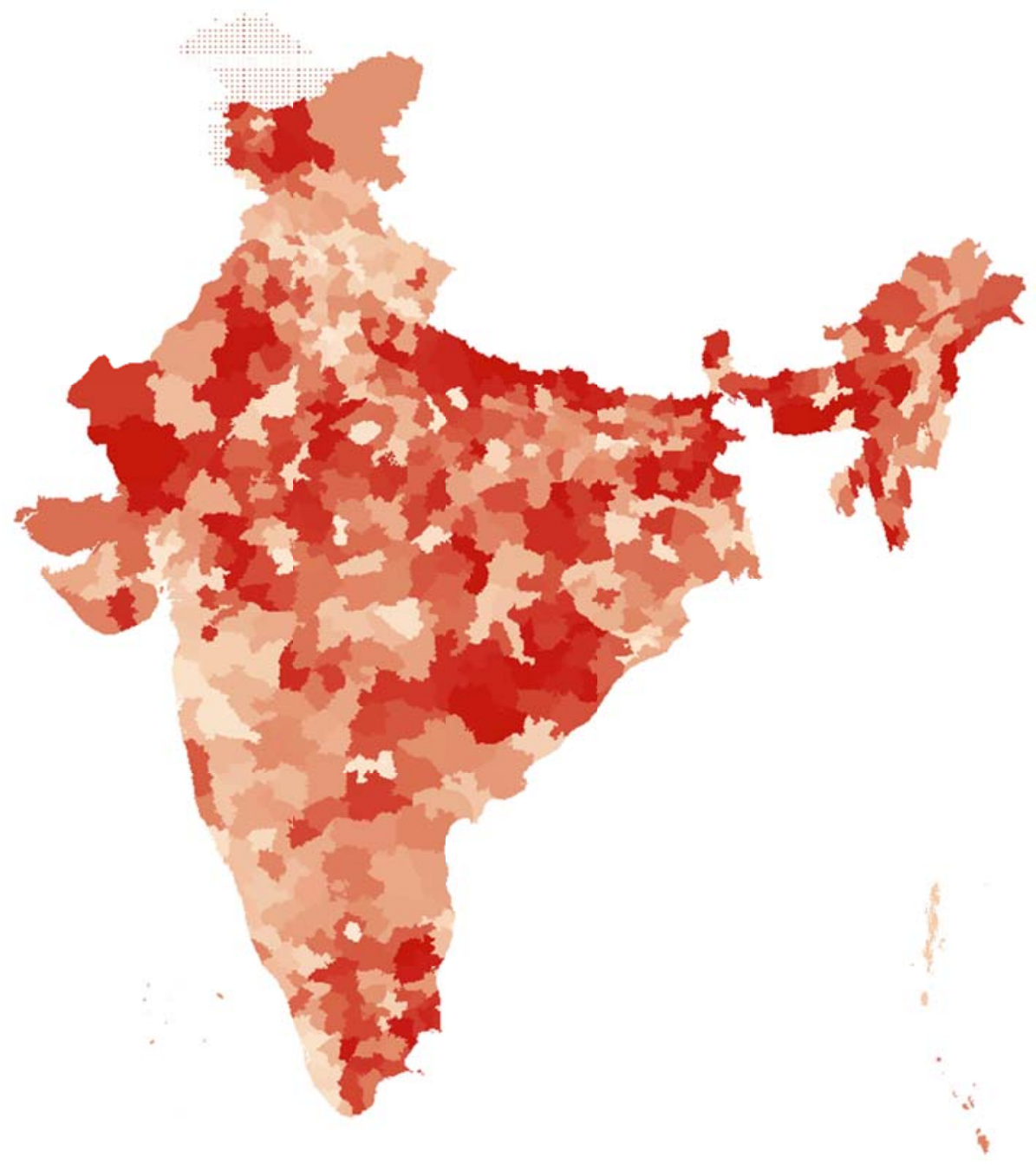

Figure 2- District-Level Share of Tertiary Education 


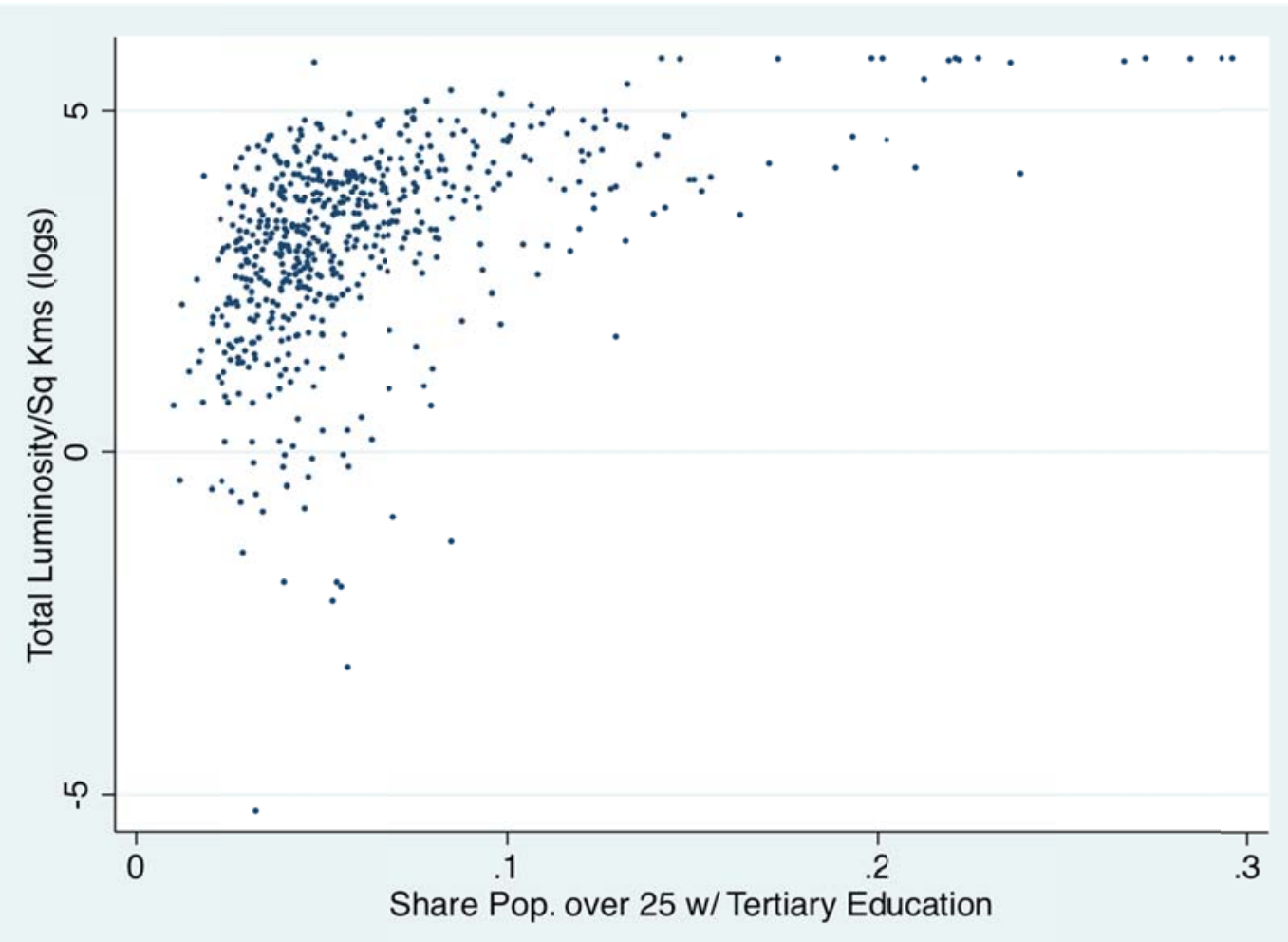

Figure 3- Tertiary Education and Night Light Density 


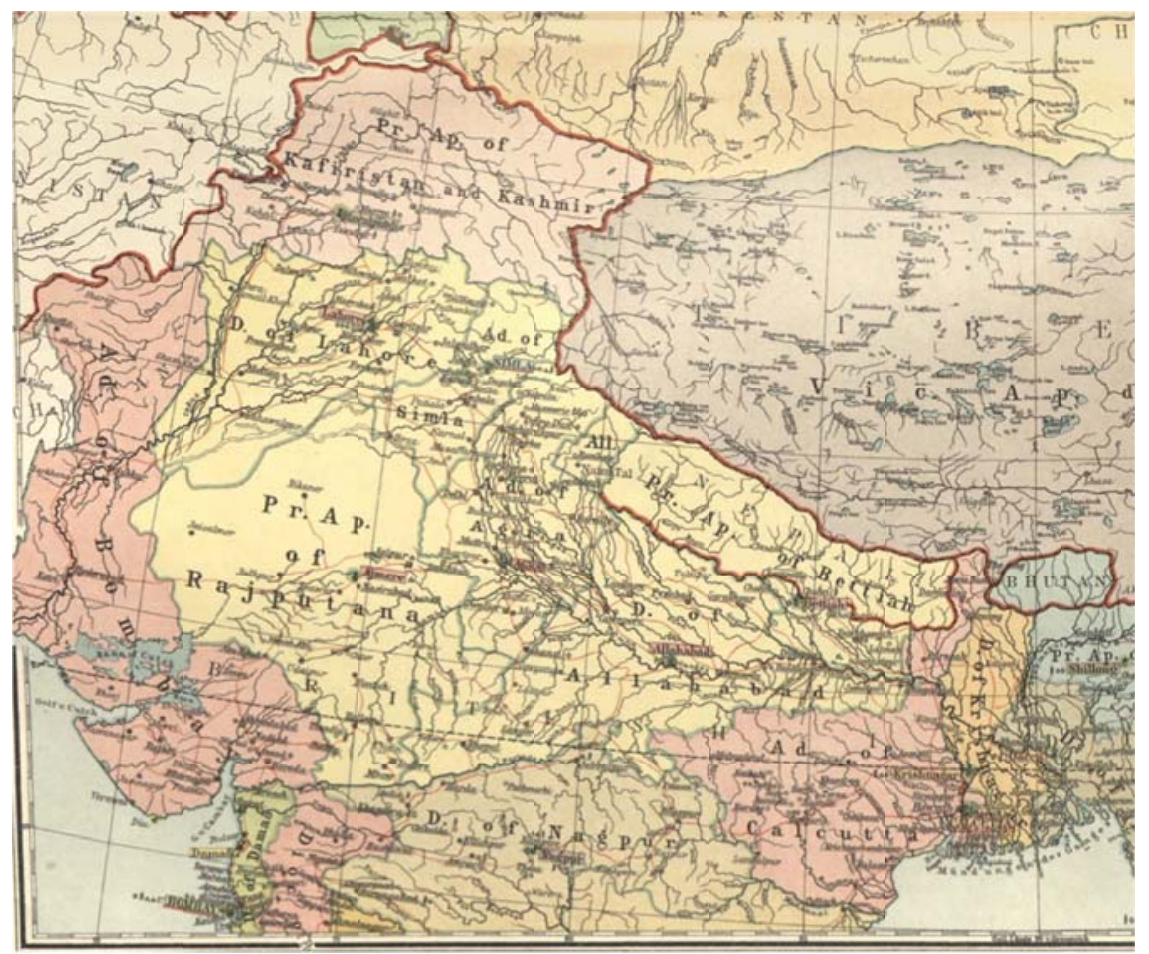

a- Historical Map, North India

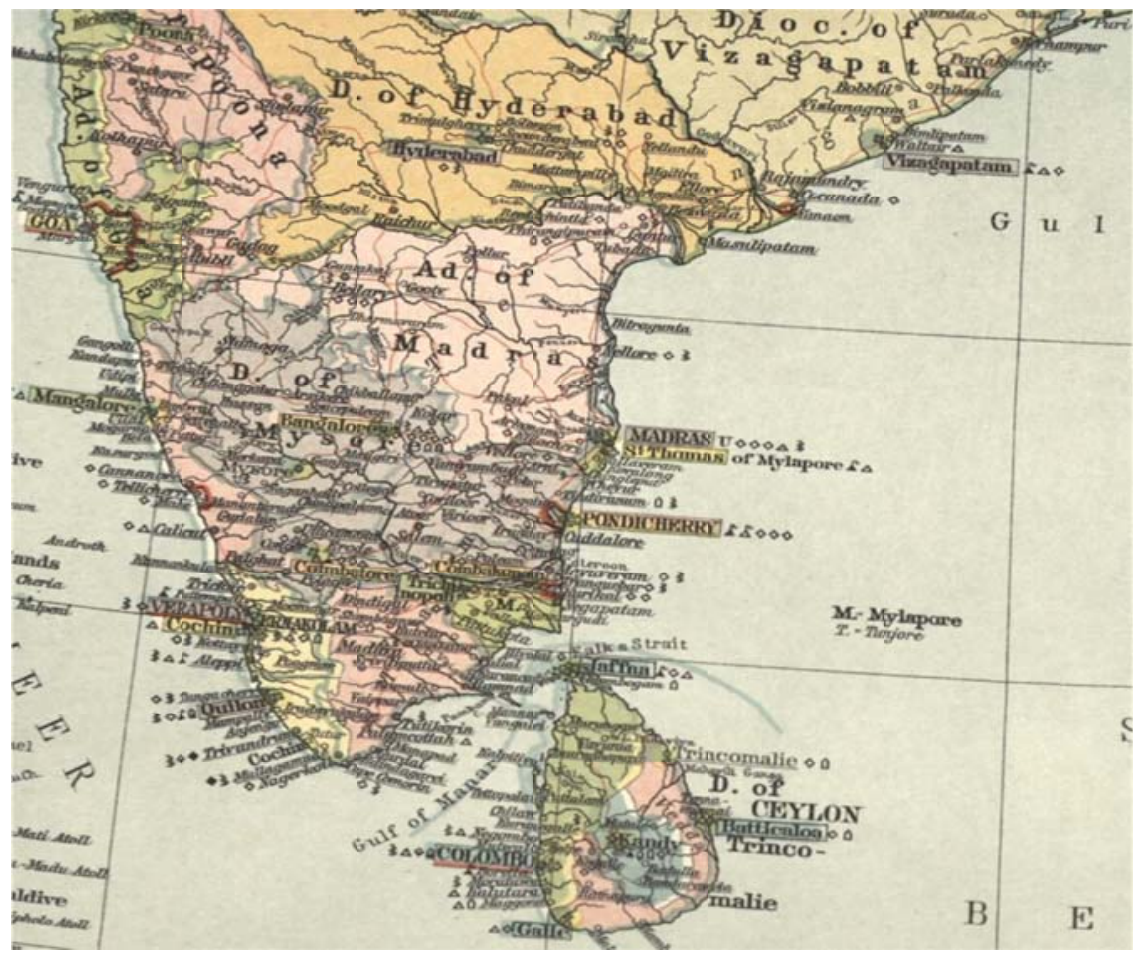

b- Historical Map, South India

Figure 4- Location of Catholic Missionaries, Atlas Hierarchicus 


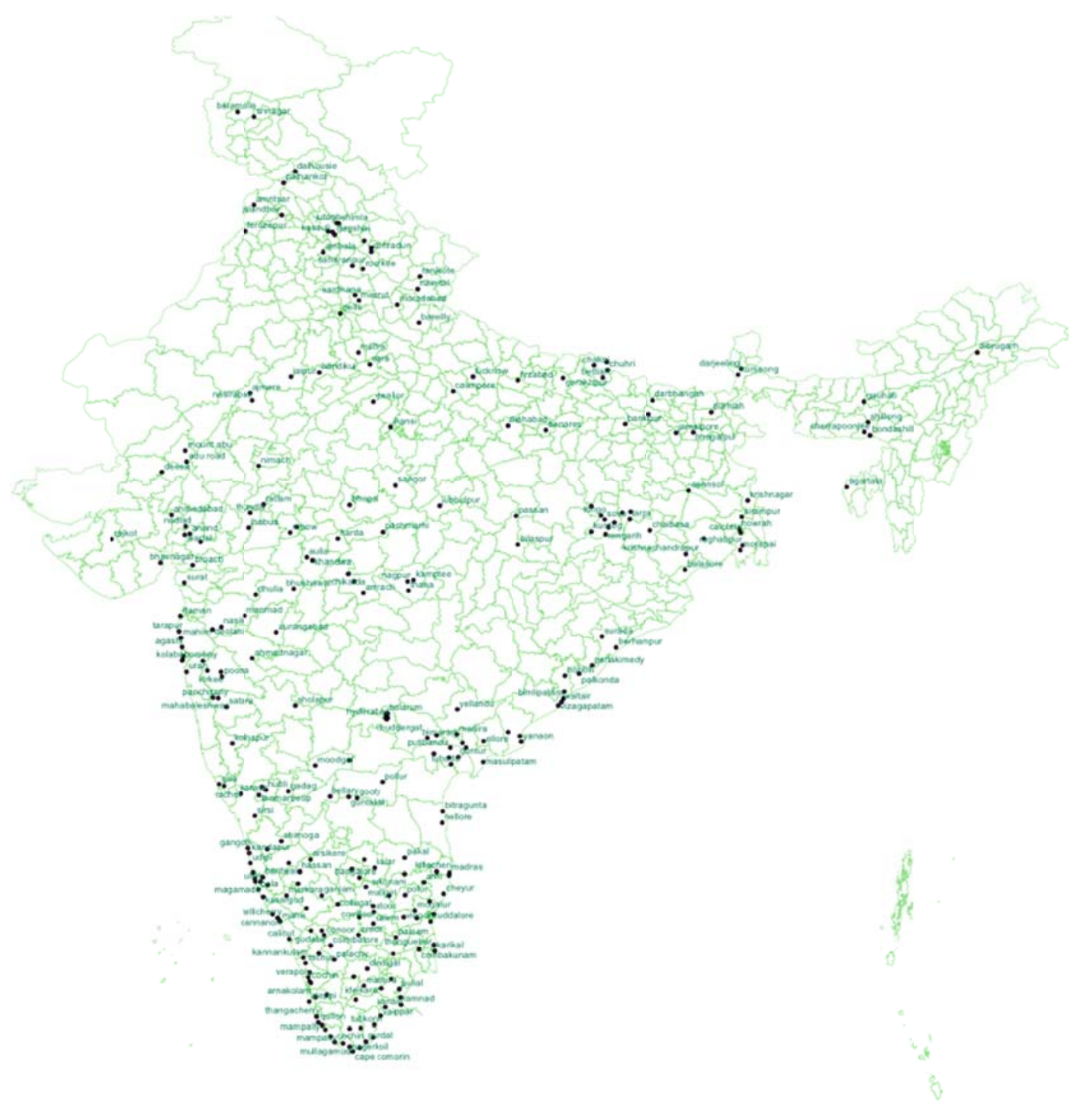

Figure 5- Catholic Missionary Location, 1911 